\title{
Review \\ Iridoids and Other Monoterpenes in the Alzheimer's Brain: Recent Development and Future Prospects
}

\author{
Solomon Habtemariam \\ Pharmacognosy Research Laboratories \& Herbal Analysis Services, University of Greenwich, Central Avenue, \\ Chatham-Maritime, Kent ME4 4TB, UK; s.habtemariam@herbalanalysis.co.uk; Tel.: +44-208-331-8302/8424
}

Received: 26 December 2017; Accepted: 5 January 2018; Published: 7 January 2018

\begin{abstract}
Iridoids are a class of monoterpenoid compounds constructed from 10-carbon skeleton of isoprene building units. These compounds in their aglycones and glycosylated forms exist in nature to contribute to mechanisms related to plant defenses and diverse plant-animal interactions. Recent studies have also shown that iridoids and other structurally related monoterpenes display a vast array of pharmacological effects that make them potential modulators of the Alzheimer's disease (AD). This review critically evaluates the therapeutic potential of these natural products by assessing key in vitro and in vivo data published in the scientific literature. Mechanistic approach of scrutiny addressing their effects in the Alzheimer's brain including the $\tau$-protein phosphorylation signaling, amyloid beta $(A \beta)$ formation, aggregation, toxicity and clearance along with various effects from antioxidant to antiinflammatory mechanisms are discussed. The drug likeness of these compounds and future prospects to consider in their development as potential leads are addressed.
\end{abstract}

Keywords: monoterpenes; iridoids; Alzheimer's disease; amyloid beta; drug likeness; multiple mechanisms

\section{Introduction}

Alzheimer's disease (AD) is one of the most prevalent age-related diseases mostly affecting the elderly population. Of the estimated 5.5 million Americans with AD in 2017, 5.3 million comprising about $96 \%$ of the patients' population, were 65 years of age or older [1]. The disease also accounts for up to $70 \%$ of all cases of dementia and has a global prevalence of about 47 million people in 2015 [2]. Moreover, the projected figure for dementia by the year 2050 is 131.5 million highlighting the rapid rate of increase in its importance. As life expectancy continues to increase all over the world in parallel with economic development, the risk of $\mathrm{AD}$ along with its cost and social burden will be felt even more in the future. The disease is characterized by progressive cognitive deficit and irreversible neuronal deterioration. To date, there is no cure for $\mathrm{AD}$ and the average lifespan between the manifestation of clinical symptoms and death is about 8.5 years [3]. The memory deficits in AD are also associated with behavioral changes making patient care management very challenging.

The therapeutic options for AD are very limited with drug therapy mainly directed at the cholinergic system by using cholinesterase inhibitors such as donepezil, galantamine, and rivastigmine. A limited benefit by using non-competitive $\mathrm{N}$-methyl-D-aspartate (NMDA) receptor antagonists including memantine have also been employed [4,5]. In the recent review article, the role of natural products in ameliorating the various neurodegenerative diseases has been outlined [6]. Significant advances in understanding the therapeutic potential of polyphenolic compounds such as flavonoids [7-12], caffeic acid derivatives [13] and aromatic diterpenoids [14] that benefit AD through multiple mechanisms of actions have also been presented. One class of compounds that has not received much attention as potential therapy for $\mathrm{AD}$ is the monoterpene class. In the present communication, a systematic review of these compounds with special emphasis on iridoids is presented. 


\section{Overview of Iridoids Chemistry}

Iridoids are the monoterpenoid class of natural products that are constructed with 10 carbon skeleton. One structural marker of this compounds is the cis-fused cyclopenta[c]pyran system that exist in nature as glycosides, aglycones, in the form of secoiridoids or bisiridoids forms (Figure 1). In the case of secoiridoids, the C7-C8 bond of the iridoid skeleton is cleaved following a series of oxidation steps to give rise to compounds like secologanin (Figure 1), which also serves as a precursor to the synthesis of alkaloids.<smiles>CC1C[C@@H]2C=COC(OC(=O)Cl)[C@H]2C1C</smiles>

Iridoid glycoside<smiles>C=C[C@@H]1[C@H](O[Cl+2]([O-])[O-])OC=C(C(=O)OC)[C@H]1CC=O</smiles>

Secologanin

Figure 1. General structure of iridoids and secoiridoids.

The biosynthesis pathway of terpenoids has been reviewed in the various literatures $[15,16]$ and involves some key biosynthetic intermediates like the mevalonic acid. Even though the starting primary metabolite goes as far back as a two-carbon metabolite, acetyl-CoA, the basic skeleton of all terpenoids is defined by the 5-carbon isoprene units in the form of isopentenyl pyrophosphate (IPP) and dimethylallyl pyrophosphate (DMAPP). The precursor of all terpenoids in the further steps of reaction is the geranyl pyrophosphate (GPP) that is made from two isoprene units (Figure 2). The sesquiterpenes (15 carbon), diterpenes (20 carbon) and triterpenes (30 carbons) are classical examples of terpenoids that arise from condensation of these isoprene units through a serious of enzyme-catalyzed reactions. The GPP gives rise to a range of cyclic and acyclic monoterpenes of biological significance [17], while the 8-hydroxygeraniol unique pathways leads to iridoids and their derivatives (Figure 2). The compounds scrutinized for their potential effect in ameliorating the biochemical and behavioral symptoms of $A D$ are shown in Figure 3.

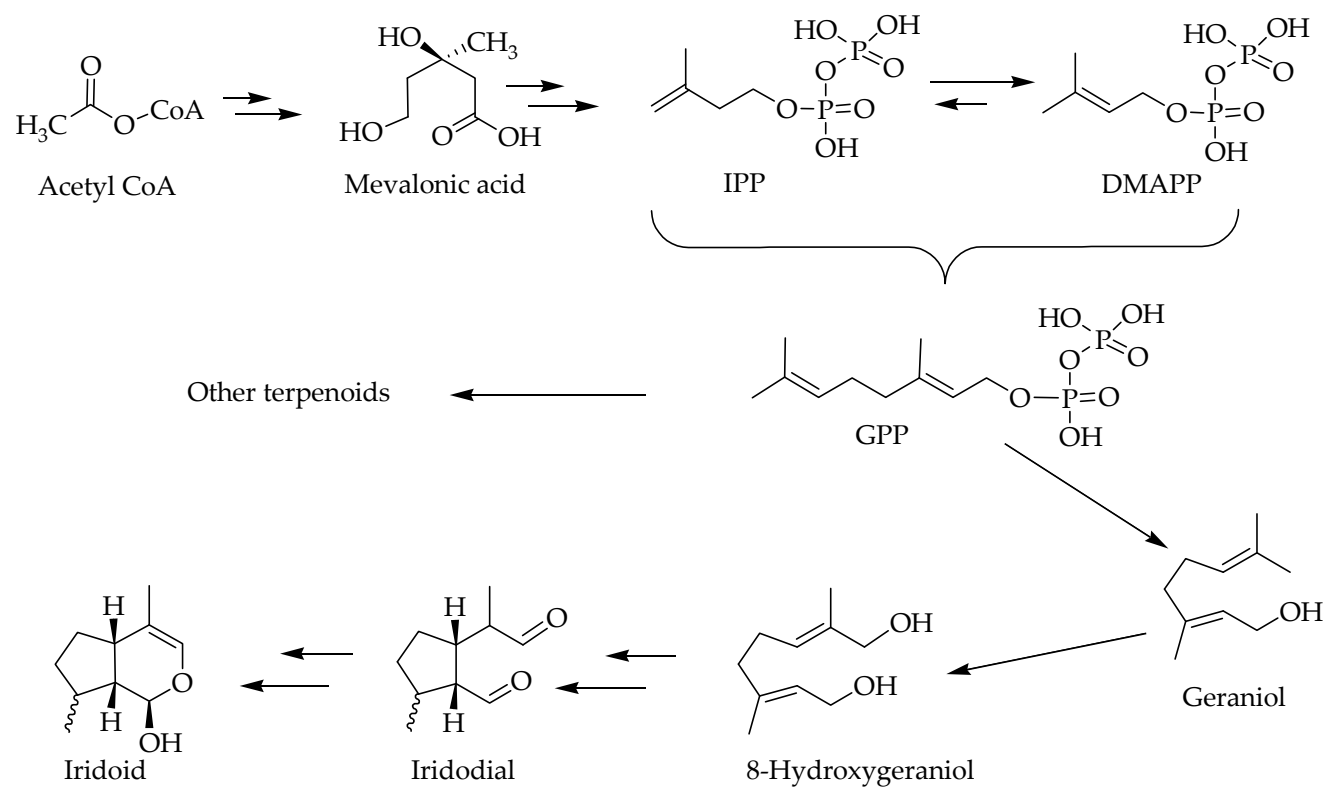

Figure 2. An overview of biosynthesis pathway of iridoids. 


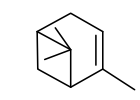

$\alpha$-Pinene<smiles>CC1(C)C2CC=C(C=O)C1C2</smiles>

Myrtenal

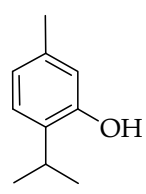

Thymol

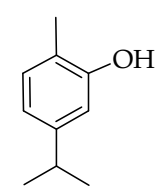

Carvacrol

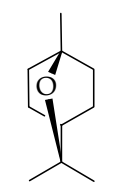

Eucalyptol (1,8-Cineole)<smiles>C=CCC(C)(O)CCC=C(C)C</smiles>

Linalool<smiles>[R]C1CC2(C)CCC1(C)C2</smiles>

$\mathrm{R}=\mathrm{H}$ Bornane $\mathrm{R}=\mathrm{OH}$ Borneol $\mathrm{R}=\mathrm{O}$ Camphor

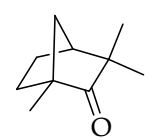

Fenchone<smiles>COC(=O)C1=COC(O)C2C(CO)=CC[C@H]12</smiles><smiles>C/C=C1\C(C(=O)OC)=CO[C@H](O[C@@H]2O[C@H](CO)[C@@H](O)[C@H](O)[C@H]2O)C1CC(=O)CCc1ccc(O)c(O)c1</smiles>

Oleuropein

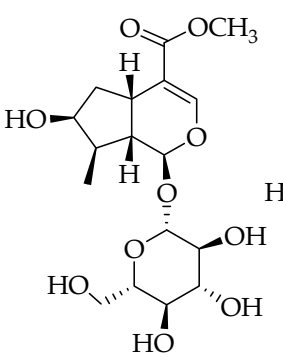

Loganin<smiles>COC(=O)C1=CO[C@@H](O)[C@H]2C(CO)=CC[C@H]12</smiles><smiles>OC[C@H]1O[C@H](CO)[C@H](O)[C@@H](O)C1O</smiles>

Geniposide

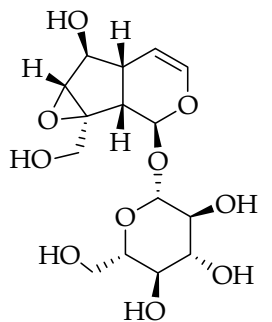

Catalpol

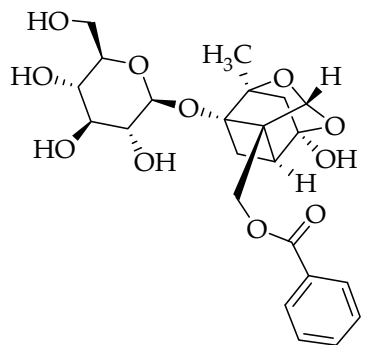

Paeoniflorin

Figure 3. Structures of compounds with potential effects on the Alzheimer's brain. Note that compounds containing a sugar moiety (oleuropein, loganin, geniposide, catalpol and paeoniflorin) are highly polar and hence are not components of essential oils.

\section{General Function of Iridoids and other Monoterpenes in Nature}

Why plants and animals produce secondary metabolites has been a century-old question that has not yet been fully answered. A number of general arguments presented in the last few decades have been based on the role of such compounds in cell-cell communication within the organism or plant-animal interactions including defense against pathogens [15,18-20]. With respect to chemical defense against herbivores and pathogens, the role of iridoids is well defined as these compounds have been demonstrated to be bitter and show good sets of biological activities [21,22]. Interestingly, animals such as butterfly are known to accumulate these chemicals as defense against pathogens [23-25]. The biological activities of iridoids in mammalian system have also been the subject of intense scrutiny in recent years and effects including antidiabetic properties have recently been reviewed along with other monoterpenes [17]. In this communication, the promise of monoterpenes, but primarily iridoids, (Figure 3) for treating AD is scrutinized by assessing published literature on their in vitro and in vivo effects.

\section{Therapeutic Potential for Alzheimer's Disease}

\subsection{In Vitro Protective Effects}

The vast arrays of neuroprotective effects of iridoids and some monoterpenes are shown in Table 1 [26-56]. The $A \beta$ formation, aggregation and function have been the major target areas of $\mathrm{AD}$ for in vitro experiments. In a study by Marumoto et al. [26], the $\beta$-secretase (recombinant human BACE1) inhibitory activities of some monoterpenes have been evaluated. Even though the inhibitory activity of these compounds were confirmed, their activity was moderate (above 
$50 \mu \mathrm{M})$ with geranyl acetone being the most active $\left(\mathrm{IC}_{50}\right.$ value of $\left.51.9 \pm 3.9 \mu \mathrm{M}\right)$ followed by (+)-camphor $(95.9 \pm 11.0 \mu \mathrm{M}),(-)$-fenchone $(106.3 \pm 14.9 \mu \mathrm{M}),(+)$-fenchone $(117.0 \pm 18.6 \mu \mathrm{M})$, and $(-)$-camphor $(134.1 \pm 16.4 \mu \mathrm{M})$. A number of in vitro experiments have also been devoted to studying the inhibitory effects of monoterpenes against $A \beta$-induced cytotoxicity in neuronal cells in vitro. Treatment of cells with borneaol suppressed the $A \beta$-induced cytotoxicity and oxidative stress in the SH-SY5Y (human neuroblastoma) cells [31] while 1,8-cineole (eucalyptol) showed similar effect in PC12 (rat pheochromocytoma) cells [32]; and genipin in cultured hippocampal neurons [34]. The antioxidant activity of these monoterpenes is also evident from their ameliorating effect on the $\mathrm{H}_{2} \mathrm{O}_{2}$-induced oxidative stress as shown by catalpol in astrocytes [29], and $\alpha$-pinene and 1,8-cineole in PC12 cells [33]. Cultured primary cortical neurons exposed to A $\beta$ could also be rescued by geniposide from toxicity and oxidative stress [37]. In a further experiment to show the mechanism of action of geniposide in primary cultured cortical neurons' protection, the geniposide-induced $\tau$ protein phosphorylation and phosphorylation of Akt at Ser- 473 site and GSK-3 $\beta$ at Ser-9 site were shown to be inhibited by leptin antagonists [38]. The role of leptin as potential mechanism of iridoids action on the Alzheimer's brain is discussed in detail in the following section.

With respect to the $A \beta$-induced toxicity in the central neuronal cells, the role of insulin-degrading enzyme (IDE) has been highlighted in recent years. In addition to degradation and clearance of $A \beta$, the IDE play pivotal role in the regulation of $A \beta$ activity. By using primary cortical neurons in a culture media, Zhang et al. [39] have demonstrated that geniposide enhance the phosphorylation of peroxisome proliferator-activated receptor $\gamma(\operatorname{PPAR} \gamma)$. The effect of geniposide in the activation of the IDE promoter was also shown to be mediated via the glucagon-like peptide-1 (GLP-1) receptor while other pathways confirmed to be involved by inhibitor studies (see Table 1) where phosphatidyl inositol 3-kinase, PI3K, proto-oncogene tyrosine-protein kinase Src (c-Src), PPAR $\gamma$, protein kinase A (PKA) and epidermal growth factor receptor (EGFR) [39,40]. Furthermore, in the SH-SY5Y cells, geniposide has been shown to ameliorate the cytotoxicity of $A \beta$ along with its oligomer assembly and cytotoxicity [41]. The protective effect of geniposide in the SH-SY5Y cells treated with other toxicants such as formaldehyde has also been reported [42]. The effect of paeoniflorin in PC12 cells protection from $A \beta$ was similar with geniposide in that its activity was correlated with upregulation of the protein kinase B (Akt) phosphorylation level, B-cell lymphoma 2 (Bcl-2) protein expression, reducing Bax protein expression and is inhibited by LY294002 [52]. The protective effect of paeoniflorin from the 6-hydroxydopamine-induced apoptosis in PC12 cells was also correlated with enhanced antioxidant capacity (GSH (glutathione - reduced form) level) and suppression of the nuclear factor kappa-light-chain-enhancer of activated B cells (NF- $\mathrm{kB}$ ) translocation [53]. A number of other studies (Table 1) also showed the protective effect of paeoniflorin against A $\beta$ cytotoxicity in PC12 cells [52-54] and SH-SY5Y cells [55]; as well as glutamate-induced cytotoxicity in PC12 cells [56].

Hydrogen peroxide $\left(\mathrm{H}_{2} \mathrm{O}_{2}\right)$-induced cytotoxicity in $\mathrm{PC} 12$ cells could be inhibited by geniposide through the PI3K-dependent pathway as evidenced from the study using a selective inhibitor, LY294002 [43]. In the same cell system, Liu et al. [44] also showed that the effect of geniposide in reversing the oxidative stress induced by $\mathrm{H}_{2} \mathrm{O}_{2}$ involves an increased level of $\mathrm{Bcl}-2$ by activation of the mitogen-activated protein kinase (MAPK), mitogen-activated protein kinase kinase (MEK) and rapidly accelerated fibrosarcoma proto-oncogene serine/threonine-protein (c-Raf) phosphorylation along with the phosphorylation of the p90 variant of the ribosomal s6 kinase (p90RSK) [43]. The requirement of the PI3K and GLP-1 receptor activation has also been confirmed in the PC12 cells protection from the $\mathrm{H}_{2} \mathrm{O}_{2}$-induced cytotoxicity [44]. 
Table 1. In vitro effects of iridoids and other monoterpenes related to AD pathology.

\begin{tabular}{|c|c|c|c|}
\hline Compound & Model & Outcome & Reference \\
\hline $\begin{array}{l}\text { Geranyl acetone; (+)-camphor; (-)-fenchone; } \\
\text { (+)-fenchone; (-)-camphor }\end{array}$ & $\beta$-secretase (recombinant human BACE1) & Moderate activity with inhibitory concentration $\left(\mathrm{IC}_{50}\right)$ higher than $50 \mu \mathrm{M}$. & [26] \\
\hline $\begin{array}{l}\text { Bornane (or camphane)-hybrids of } \\
\text { Galantamine }\end{array}$ & $\begin{array}{l}\text { Docking-based design and synthesis of } \\
\text { galantamine-camphane hybrids. }\end{array}$ & Hybrids showed over 191-better inhibition of AChE than galantamine & [27] \\
\hline Catalpol & PC12 cells-A $-\mathrm{A} 25-35$ & 10 and $100 \mu \mathrm{L}-$ Increase expression and activity of ChAT. & [28] \\
\hline Catalpol & $\begin{array}{l}\mathrm{H}_{2} \mathrm{O}_{2} \text {-induced oxidative stress in } \\
\text { astrocytes; primary cultures in mice. }\end{array}$ & $\begin{array}{l}\text { 50-500 } \mu \mathrm{M}-\text { Increase cell viability; reduce the intracellular level of ROS; suppress oxidative stress by restoring the activities } \\
\text { of antioxidant enzymes (GPx, GR and GSH); no effect on CAT activity. }\end{array}$ & [29] \\
\hline Catalpol & CHO cells & 10 and $100 \mu \mathrm{M}-$ No effect on $\mathrm{AChE}$ activity; elevate the $\mathrm{M}-2$ receptor density but did not occupy the $\mathrm{M}$ receptor binding site. & [30] \\
\hline$(-)$ - and (+)-Borneol & $\begin{array}{l}\text { A } \beta \text {-induced oxidative stress in } \\
\text { SH-SY5Y cells }\end{array}$ & $\begin{array}{l}100 \mu \mathrm{M} \text {-Inhibit cytotoxicity; decrease ROS generation; increase HO-1 and nuclear translocation of Nrf2 expressions; } \\
\text { increase Bcl-2 while decreasing Bax expression. }\end{array}$ & [31] \\
\hline 1,8-cineole (eucalyptol) & $A \beta(25-35)$ treated $P C 12$ cells & $\begin{array}{l}\text { Restored cell viability; reduce mitochondrial membrane potential, ROS and NO levels; suppress the levels of } \\
\text { proinflammatory cytokines (TNF- } \alpha \text {, IL-1 } \beta \text { and IL-6); lower the expression of NOS-2, COX-2 and NF-kB. }\end{array}$ & [32] \\
\hline 1,8 -Cineole and $\alpha$-Pinene & $\mathrm{H}_{2} \mathrm{O}_{2}$-induced oxidative stress in $\mathrm{PC} 12$ & $\begin{array}{l}\text { Inhibit the level of iROS; enhance the expression of antioxidant enzymes (CAT, SOD, GPx, GR and HO-1. Decrease apoptosis } \\
\text { (reduce capase-3 activity); induce the nuclear Nrf2 factor. }\end{array}$ & [33] \\
\hline Genipin & $\begin{array}{l}\text { Cultured hippocampal neurons treated } \\
\text { with A } \beta-25-35\end{array}$ & 20-40 $\mu \mathrm{M}-$ Reduce LDH release; improve morphological appearance. & [34] \\
\hline Genipin & $\begin{array}{l}\text { Cultured rat brain microglial cells } \\
\text { treated with LPS }\end{array}$ & $\begin{array}{l}\text { 5-20 } \mu \mathrm{M} \text { - Inhibit NO release; suppress the level of TNF, interleukin-1 } \beta, \text { PGE-2, iROS; suppress NF- } \mathrm{kB} \text { activation; reduce NO } \\
\text { release stimulated by IF- } \gamma \text { and A } \beta .\end{array}$ & [35] \\
\hline Genipin & $\begin{array}{l}\text { A23187 (a calcium ionophore)-induced } \\
\text { cytotoxicity in neuro2a cells }\end{array}$ & 8 and $20 \mu \mathrm{M}-$ Cytoprotective effect from caspase $3 / 7$ and ER stress. & [36] \\
\hline Geniposide & $\begin{array}{l}\text { Cultured primary cortical neurons } \\
\text { treated with } A \beta\end{array}$ & $\begin{array}{l}\text { Reverse mitochondrial dysfunction by recovering ATP generation, MMP, and cytochrome c oxidase and caspase 3/9 activity; } \\
\text { reduce ROS production and cytochrome c leakage; inhibit apoptosis. }\end{array}$ & [37] \\
\hline Geniposide & Rat primary cultured cortical neurons & $\begin{array}{l}\text { Decrease the phosphorylation of } \tau \text { protein while inducing the phosphorylation of Akt at Ser-473 site and GSK-3ß at Ser-9 } \\
\text { site; effect could be prevented by leptin antagonist. }\end{array}$ & [38] \\
\hline Geniposide & $\begin{array}{l}\text { Primary cortical neurons and PC12 } \\
\text { cells-insulin-degrading enzyme (IDE) } \\
\text { in the degradation and activity of }(\mathrm{A} \beta)\end{array}$ & $\begin{array}{l}\text { Up-regulation of IDE by geniposide inhibited by LY294002 (inhibitor of PI3K), PP1 (inhibitor for c-Src), GW9662 (antagonist } \\
\text { of PPAR } \gamma \text { ), H89 (inhibitor of PKA) and AG1478 (antagonist of EGFR). Enhanced the phosphorylation of PPAR } \gamma \text {; accelerate } \\
\text { the release of phosphorylated FoxO1 (forkhead box O1) from nuclear fraction to the cytosol; directly activate the activity of } \\
\text { IDE promoter in PC12 cells. }\end{array}$ & {$[39,40]$} \\
\hline Geniposide & SH-SY5Y cells treated with $A \beta$ & 5-200 $\mu \mathrm{M}-$ Decrease cytotoxicity by remodeling $\mathrm{A} \beta$ assembly. & [41] \\
\hline Geniposide & SH-SY5Y treated with formaldehyde & $\begin{array}{l}\text { Restore normal morphology and inhibit apoptosis in dose dependent manor; increase the activity of intracellular } \\
\text { antioxidants (SOD and GPx); increase antiapoptotic gene Bcl-2 while downregulating the expression of apoptotic-related } \\
\text { gene (P53, caspase } 3 \text { and caspase 9). }\end{array}$ & [42] \\
\hline Geniposide & $\mathrm{H}_{2} \mathrm{O}_{2}$-induced cytotoxicity in $\mathrm{PC} 12$ cells & $\begin{array}{l}\text { Induce the expression of the antiapoptotic protein Bcl-2; inhibit apoptosis; effect dependent on PI3K (inhibited by LY294002); } \\
\text { enhance the phosphorylation of Akt308, Akt473, GSK-3 } \beta \text { and PDK1 under oxidative stress. }\end{array}$ & [43] \\
\hline Geniposide & $\mathrm{H}_{2} \mathrm{O}_{2}$-induced cytotoxicity in $\mathrm{PC} 12$ cells & $\begin{array}{l}\text { 25-100 } \mu \mathrm{g} / \mathrm{mL}-\text { Increase the expression of anti-apoptotic proteins (including Bcl-2 and HO-1); effect inhibited by LY294002; } \\
\text { increase Bcl-2 level by activation of MAPK, MEK and c-Raf phosphorylation; effect inhibited by U0126 (inhibitor of MEK). }\end{array}$ & [44] \\
\hline Loganin & $\begin{array}{l}\text { Organotypic cultured } \\
\text { hippocampal tissues }\end{array}$ & Increased the total activity of fEPSP after high frequency stimulation. & [45] \\
\hline
\end{tabular}


Table 1. Cont.

\begin{tabular}{|c|c|c|c|}
\hline Compound & Model & Outcome & Reference \\
\hline Loganin & $\begin{array}{l}\mathrm{AChE}, \mathrm{BChE} \text {, and } \beta \text {-site amyloid } \\
\text { precursor protein cleaving enzyme } 1 \\
\text { (BACE1) }\end{array}$ & $\mathrm{AChE}$ inhibitory effects with $\mathrm{IC}_{50}$ values for $\mathrm{AChE}$ and $\mathrm{BChE}$ of 0.33 and $37.78 \mu \mathrm{M}$, respectively. & [46] \\
\hline Loganin & $\begin{array}{l}\text { A } 325-35 \text {-induced inflammatory damage } \\
\text { in PC12 cells }\end{array}$ & $\begin{array}{l}\text { Inhibit cytotoxicity by suppressing ROS generation; inhibit apoptosis by suppressing caspase-3 activity and regulating cell } \\
\text { cycle; suppress the level of TNF- } \alpha \text { and protein expression of iNOS and COX-2; inhibit NF-KB activation by modulating } \\
\text { degradation of the inhibitory subunit IKB; inhibit phosphorylation of MAPKs (ERK1/2, p38 and JNK). }\end{array}$ & {$[47,48]$} \\
\hline Loganin & $\beta$-Secretase (BACE1) & $92 \mu \mathrm{M}$-Inhibit BACE1 with little effect on $\alpha$-secretase. & [49] \\
\hline Myrtenal & Anti-acetylcholinesterase activity & $\begin{array}{l}\text { 1,8-cineole, carvacrol, myrtenal and verbenone } \mathrm{AChE} \text {; the highest inhibitory activity was observed for myrtenal } \\
\qquad\left(\mathrm{IC}_{50}=170 \mu \mathrm{M}\right) .\end{array}$ & [50] \\
\hline $\begin{array}{l}\text { Thymol and carvacrol derivatives with added } \\
\text { carbamate moiety-Synthesis }\end{array}$ & $\begin{array}{l}\text { Acetylcholinesterase and } \\
\text { butyrylcholinesterase inhibition assay }\end{array}$ & $\begin{array}{l}\text { 5-isopropyl-2-methylphenyl(3-fluorophenyl)carbamate was found to be the most potent } \mathrm{AChE} \text { inhibitor with } \mathrm{IC}_{50} \text { values of } \\
2.22 \mu \mathrm{M} \text {; 5-isopropyl-2-methylphenyl (4-fluorophenyl)carbamate exhibited the strongest inhibition against BuChE with IC } \mathrm{IC}_{50} \\
\text { value of } 0.02 \mu \mathrm{M} \text {. }\end{array}$ & [51] \\
\hline Paeoniflorin & A $\beta 25-35$-induced PC12 cell injury & $\begin{array}{l}10 \mu \mathrm{M}-\text { Inhibit cytotoxicity; upregulate AKT phosphorylation; increase Bcl-2 protein expression, reduce Bax protein } \\
\text { expression and caspase-3 activation. Effect reversed by LY294002. }\end{array}$ & [52] \\
\hline Paeoniflorin & $\begin{array}{l}\text { 6-Hydroxydopamine-induced apoptosis } \\
\text { in PC12 cells }\end{array}$ & $\begin{array}{l}\text { 30-300 } \mu \mathrm{M} \text {-Suppresses mitochondria-mediated apoptosis; increase GSH level; attenuate the 6-OHDA-induced NF-kB } \\
\text { translocation without affecting phosphorylation of Akt, JNK, p38, and ERK1/2; blocked the induced protein kinase C } \delta \\
\text { (PKC } \delta \text { ) upregulation. }\end{array}$ & [53] \\
\hline Paeoniflorin & $\begin{array}{l}\text { A } \beta 25-35 \text {-induced neurotoxicity in } \\
\text { PC12 cells }\end{array}$ & $\begin{array}{l}\text { 2-50 } \mu \mathrm{M}-\text { Attenuate cytotoxicity mediated through mitochondrial dysfunction (decreased mitochondrial membrane } \\
\text { potential, increased cytochrome c release as well as activity of caspase-3 and caspase- } 9 \text { ). }\end{array}$ & [54] \\
\hline Paeoniflorin & $\begin{array}{l}\text { A } 325-35 \text {-induced cytotoxicity in } \\
\text { SH-SY5Y cells }\end{array}$ & $\begin{array}{l}\text { Restore cell viability; inhibit apoptotic and ROS production; inhibit mitochondrial dysfunction (mitochondrial membrane } \\
\text { potential, increased Bax/Bcl-2 ratio, cytochrome c release and activity of caspase-3 and caspase-9). }\end{array}$ & [55] \\
\hline Paeoniflorin & $\begin{array}{l}\text { Glutamate-induced cytotoxicity in } \\
\text { PC12 cells }\end{array}$ & 0.1-10 $\mu \mathrm{M}-$ Protect cells from cytotoxicity; up-regulate Bcl-2 and down-regulate Bax. & [56] \\
\hline
\end{tabular}

Bax, Bcl-2-associated X protein (bcl-2-like protein 4); CAT, Catalase; EGFR, epidermal growth factor receptor; ER, endoplasmic reticulum GPx, glutathione peroxidase; GR, glutathione reductase; GSH, glutathione - reduced form; GSK-3 $\beta$, glycogen synthase kinase $3 \beta$; IF- $\gamma$, interferon- $\gamma$; iNOS, inducible nitric oxide synthase; iROS, intracellular ROS; LDH, lactate dehydrogenase; MMP, mitochondrial membrane potential; NOS, nitric oxide synthase; Nrf2, nuclear factor erythroid 2; PDK1, 3-phosphoinositide-dependent protein kinase-1; fEPSP, field excitatory postsynaptic potential. 
The antiinflammatory effect of these compounds in the CNS came from evidences in vitro showing the inhibition of nitric oxide (NO) release from the lipopolysaccharide (LPS)-stimulated microglia by genipin along with suppression of microglial cells activation [34]. Beyond suppression of NO production, genipin also ameliorated the LPS-induced tumour necrosis factor- $\alpha$ (TNF), interleukin- $1 \beta$ (IL-1), prostaglandin E2 (PGE-2), intracellular reactive oxygen species (iROS), and NF-kB activation in microglial cells in vitro [35].

In an organotypic cultured hippocampal tissues, the scopolamine-induced functional changes was shown to be inhibited by loganin along with inhibition of acetylcholinesterase (AChE), butyrylcholinesterase (BChE) and $\beta$-secretase (BACE1) [45]. An effect on $\beta$-secretase (BACE1) inhibitory activity of loganin has also been reported by Youn et al. [49]. A direct effect on one of the most prevalent $\mathrm{AD}$ target, $\mathrm{AChE}$, for loganin with $\mathrm{IC}_{50}$ value in sub-micromolar range was particularly impressive [46]. A further molecular docking studies have shown that loganin's non-competitive type of interaction generate a negative binding energies for cholinesterase as well as BACE1 suggesting a high affinity and tighter binding capacity for the active site of the enzymes [46]. As BChE (though to a lesser extent, see Table 1) is also inhibited, loganin appear to target AChE, BChE, and BACE1 that are all important in AD pathology. The A $\beta$-induced inflammatory changed in $\mathrm{PC} 12$ cells could also be inhibited by loganin as evidenced from a reduction in the level of TNF- $\alpha$ and protein expression of iNOS and cyclooxygenase-2 (COX-2) [47,48]. These effects were also correlated with inhibition of NF- $\mathrm{KB}$ along with the closely related regulatory pathways including the phosphorylation of MAPKs (ERK1/2 (Extracellular signal-regulated kinase $\frac{1}{2}$ ), p38 and JNK (c-Jun N-terminal kinase) [47].

A number of other studies (Table 1) have shown that monoterpenes possess direct inhibitory effect against AChE activity. This includes a report by Kaufmann et al. [50] on 8-cineole, carvacrol, myrtenal and verbenone, although the best activity in this study was observed at relatively high concentration $\left(\mathrm{IC}_{50}=170 \mu \mathrm{M}\right.$ for myrtenal). On the other hand, oleuropein, thymol and carvacrol have been shown to have a much better activity but the best activity $\left(\mathrm{IC}_{50}<5 \mu \mathrm{M}\right)$ was obtained when a carbamate moiety was added to carvacrol through a synthesis approach [51]. In the latter case, there has also been a drive to improve the biological activity of existing anti-Alzheimer's drugs by incorporating the monoterpene skeleton through synthesis. For example, with the help of a docking-based design, galantamine-camphane hybrids have been shown to display over a 100-fold better activity in AChE inhibition than galantamine [27].

All the in vitro data is shown in Table 1, which clearly indicates the therapeutic potential of iridoids as well as other monoterpenes in AD. The gross inhibition of cytotoxicity in neuronal cells induced by $A \beta$ and other toxic agents have been demonstrated to be ameliorated. The reactive oxygen species (ROS), proinflammatory cytokines and many mediators could also be suppressed while mitochondrial deterioration was inhibited. At the molecular level, a range of antioxidant proteins and enzymes could be enhanced by these natural products along with anti-apoptotic genes and proteins, while proapoptotic genes and proteins appear to be suppressed (Table 1).

\subsection{Evidence of Efficacy Demonstrated through In Vivo Studies}

In parallel with the overwhelming in vitro data, animal studies on iridoids and some other monoterpenes (Table 2) have shown potential therapeutic effects for treating AD [57-77]. The neuroprotective effect of carvacrol in vivo was studied by Zhong et al. [55] using the intracerebral hemorrhage mouse model, where a significant reduction of the aquaporin-4 (AQP4)-dependent oedema was observed. It is worth noting that AQP4 is a water channel in the brain that plays major role in the development of cerebral oedema. The structural, physiological and pathological significance of ACQ4 has been extensively reviewed [78-82]. Considering the pathophysiological role of AQP4 in a range of CNS disorders including ischemic stroke [83], neuroinflammation [84] and autoimmune neurodegenerative diseases [85], the reversal of cerebral oedema induced through AQP4 activity by monoterpenes is an interesting observation. 
Table 2. In vivo effects of iridoids and some other monoterpenes as potential modulators of AD.

\begin{tabular}{|c|c|c|c|}
\hline Compound & Model & Outcome & Reference \\
\hline Carvacrol & $\begin{array}{l}\text { Bacterial collagenase-induced intracerebral hemorrhage mouse } \\
\text { model - Single doses of } 10,25,50 \text { or } 100 \mathrm{mg} / \mathrm{kg} \text {, i.p. }\end{array}$ & $\begin{array}{l}\text { Improve neurological deficits; reduce cerebral edema and Evans blue leakage; decrease AQP4 mRNA in a } \\
\text { dose-dependent manner; reduce AQP4 protein expression in the perihematomal area. }\end{array}$ & [57] \\
\hline Catalpol & $\mathrm{D}^{-(+)}$-galactose mice model $-20 \mathrm{mg} / \mathrm{kg}$, intragastric for 30 days & $\begin{array}{l}\text { Reduce the oxidative stress in the cerebral cortex; regulate the activities and concentration of SOD, } \\
\text { glutathione peroxidase and catalase (MDA level not altered); reduce the levels of soluble A } \beta 40 \text { and A } \beta 42 \text { in } \\
\text { the cerebral cortex; effects regulated by IDE; improve learning and memory in Morris water maze test. }\end{array}$ & [58] \\
\hline Catalpol & $\begin{array}{l}\text { A } \beta 25-35 \text { injected in rats intracerebroventricularly to establish } \\
\text { AD model }-5 \text { or } 10 \mathrm{mg} / \mathrm{kg} \text {, i.p. for } 7 \text { days }\end{array}$ & $\begin{array}{l}\text { More positive neurons (ChAT staining in cerebral cortex) and cells arranged in order; increase ChAT activity } \\
\text { in dose dependent manner. }\end{array}$ & [28] \\
\hline Catalpol & $\begin{array}{l}\text { Orthotopic injection of } A \beta 25-35 \text { into the right lateral ventricle } \\
\text { of rats }-5 \text { and } 10 \mathrm{mg} / \mathrm{kg}\end{array}$ & $\begin{array}{l}\text { Increase serum hydrocortisone level; decrease ACTH and CRH levels; alleviate structural damage of } \\
\text { the hypothalamus. }\end{array}$ & [59] \\
\hline Catalpol & $\begin{array}{l}\text { Senescent mice treated with } \mathrm{D}^{-} \text {galactose }-2.5,5 \text { or } 10 \mathrm{mg} / \mathrm{kg} \text {, } \\
\text { subcutaneous for } 2 \text { weeks }\end{array}$ & $\begin{array}{l}\text { Reverse the following senescence markers: increased AChE activity, decrease in ChAT positive neurons, } \\
\text { decline in muscarinic AChR M1 (mAChR1) expression; increase in TNF- } \alpha, \text { IL-1 } \beta \text { ) and AGEs levels. }\end{array}$ & [60] \\
\hline Catalpol & $\begin{array}{l}\text { Subcutaneously injected with } \mathrm{D} \text {-galactose in mice-2.5, } 5 \text { or } \\
10 \mathrm{mg} / \mathrm{kg} \text {, subcutaneously for } 2 \text { weeks }\end{array}$ & $\begin{array}{l}\text { Reverse cognition deficit and altered biochemical changes: increased LDH and decreased activities of } \\
\text { GSH-ST, glutamine synthetase, creatine kinase in brain cortex and hippocampus. }\end{array}$ & {$[61,62]$} \\
\hline Geniposide & $\begin{array}{l}\text { APP/PS double transgenic AD mice model coupled with } \\
\text { STZ-induced diabetes }-5,10 \text {, or } 20 \mathrm{mg} / \mathrm{kg} \text { intragastric for } \\
4 \text { weeks. }\end{array}$ & $\begin{array}{l}\text { Decrease the concentrations of cerebral A } \beta 1-40 \text { and A } \beta 1-42 \text {; up-regulate the protein levels of } \beta \text {-site APP } \\
\text { cleaving enzyme (BACE1) and IDE; decrease the protein levels of ADAM10. }\end{array}$ & [63] \\
\hline Geniposide & $\begin{array}{l}\mathrm{APP} / \mathrm{PS} 1 \text { doubly transgenic mice-12.5, } 25 \text { or } 50 \mathrm{mg} / \mathrm{kg} \text {, } \\
\text { intragastric for } 3 \text { months }\end{array}$ & $\begin{array}{l}\text { Ameliorate the A } \beta 1-42 \text { induced decrease in synapse-related proteins (p-CaMKII } \alpha / \text { CaMKII } \alpha \text {, } \\
\text { p-CREB/CREB, synaptophysin, and PSD-95) in neurons and APPswe/PS1dE9 mice; reverse the } \\
\text { A } \beta 1-42 \text { induced decrease in spine density on dendrites. }\end{array}$ & [64] \\
\hline Geniposide & $\begin{array}{c}\mathrm{APP} / \mathrm{PS} 1 \mathrm{AD} \text { transgenic mice }-25 \mathrm{mg} / \mathrm{kg} \text { for three months via } \\
\text { intragastric administration }\end{array}$ & $\begin{array}{l}\text { Improves learning and memory; suppresses the RAGE-dependent signaling (activation of ERK and } \\
\text { IKB } / \mathrm{NF}-\mathrm{kB} \text { ), production of TNF- } \alpha \text { and IL-1 } \beta \text {, and cerebral A } \beta \text { accumulation; augments synaptic plasticity } \\
\text { by attenuating the A } \beta \text {-induced reduction of long-term potentiation and increasing the mEPSC amplitude } \\
\text { and frequency in hippocampal neurons; reduces oxidative stress and mitochondrial dysfunction } \\
\text { (increase the mitochondrial membrane potential). }\end{array}$ & {$[65,66]$} \\
\hline Geniposide & $\begin{array}{l}\text { STZ-induced AD model in rats-injection }(50 \mu \mathrm{M}, 10 \mu \mathrm{L}) \text { to the } \\
\text { lateral ventricle }\end{array}$ & $\begin{array}{l}\text { Prevent spatial learning deficit; reduce } \tau \text { protein phosphorylation; elevate expression of GSK3 } \beta(\mathrm{pS}-9) \text { while } \\
\text { suppressing GSK3 } \beta \text { (pY-216); improve the altered neuronal ultrastructure. }\end{array}$ & [67] \\
\hline Geniposide & $\begin{array}{l}\mathrm{A} \beta 1-42 \text { in the hippocampus of STZ-induced diabetic rats. } \\
12.5 \text { or } 25 \mathrm{mg} / \mathrm{kg} \text {, intragastric for } 46 \text { days }\end{array}$ & Improve insulin and blood glucose; decrease $A \beta 1-42$ level; improve the expression of IDE. & [68] \\
\hline Linalool & $\begin{array}{l}\text { A } \beta 1-40(4 \mu \mathrm{g}) \text { solution injected in the bilateral hippocampus in } \\
\text { mice- }-100 \mathrm{mg} / \mathrm{kg} \text {, i.p. }\end{array}$ & $\begin{array}{l}\text { Improve cognitive performance in Morris water maze test and step-through test; reverse the A } \beta 1-40 \\
\text { induced hippocampal cell injury in histological examination, apoptosis in TUNEL assay, changes of } \\
\text { oxidative stress indicators (SOD, GPx, AChE); suppress the activated cleaved caspase (caspase-3, caspase-9) } \\
\text { while elevating Nrf2, HO-1 expression. }\end{array}$ & [69] \\
\hline Linalool & $\begin{array}{l}\text { triple transgenic model of } \mathrm{AD} \text { mice }-25 \mathrm{mg} / \mathrm{kg} \text {, p.o. every } 48 \mathrm{~h} \\
\text { for } 3 \text { months }\end{array}$ & $\begin{array}{l}\text { Improve learning and spatial memory and greater risk assessment behavior in the elevated plus maze; in } \\
\text { the Hippocampi and amygdalae region, reduce extracellular } \beta \text {-amyloidosis, tauopathy, astrogliosis, } \\
\text { microgliosis and pro-inflammatory markers (p38 MAPK, NOS-2, COX-2 and IL-1 } \beta \text { ). }\end{array}$ & [70] \\
\hline
\end{tabular}


Table 2. Cont.

\begin{tabular}{|c|c|c|c|}
\hline Compound & Model & Outcome & Reference \\
\hline Loganin & Scopolamine-induced AD model in rats—40 mg $/ \mathrm{kg}$, p.o. & $\begin{array}{l}\text { Reverse shortening of step-through latency in the passive avoidance test; reduce the percent alternation in } \\
\text { the Y-maze, and increased memory retention in the Morris water maze test. }\end{array}$ & [45] \\
\hline Loganin & $\begin{array}{l}\text { Scopolamine-induced AD model in mice-20 or } 40 \mathrm{mg} / \mathrm{kg} \text {, p.o. } \\
\text { single dose }\end{array}$ & $\begin{array}{l}\text { Reverse the memory impairment (Y-maze test; passive avoidance and the Morris water maze tests); inhibit } \\
\text { AChE activity in the hippocampus and frontal cortex. }\end{array}$ & [71] \\
\hline Oleuropein & $\begin{array}{l}\text { Pentylenetetrazole-induced seizures in male NMRI mice- }-10, \\
\qquad 20 \text { or } 30 \mathrm{mg} / \mathrm{kg} \text {; i.p. }\end{array}$ & Increased the seizure threshold; anticonvulsant effects reversed by naltrexone (opioid receptor antagonist). & [72] \\
\hline Oleuropein & $\begin{array}{l}\text { Colchicine }(15 \mu \mathrm{g} / \mathrm{rat}) \text { injected into the CA1 area of the } \\
\text { hippocampus-10, } 15 \text { or } 20 \mathrm{mg} / \mathrm{kg} \text {, p.o. for } 10 \text { days }\end{array}$ & $\begin{array}{l}\text { Improve learning and memory retention (Morris water maze test); attenuate the oxidative damage } \\
\text { (assessed by GPx and CAT activities, nitric oxide and MDA). }\end{array}$ & [73] \\
\hline Paeoniflorin & Transgenic mouse model of AD-2.0 mg/kg, i.p. for $24 \mathrm{~h}$. & $\begin{array}{l}\text { Improve cognitive function and ameliorate patterns of escape distance and escape latency in AD mice; } \\
\text { decrease inflammation (protein expression levels of NF- } \mathrm{B} \text {, TNF- } \alpha \text {, IL- } 1 \beta \text {, IL- } 6 \text { and caspase- } 3 \text { activity; } \\
\text { inhibit cell death via increasing the Bcl-2/Bax ratio and p-Akt expression levels, and downregulating p-p38 } \\
\text { MAPK expression in AD mice. }\end{array}$ & [74] \\
\hline Paeoniflorin & Transgenic mouse model of AD—4 week treatment & $\begin{array}{l}\text { Inhibit } A \beta \text { burden, } A \beta \text {-induced over activation of astrocytes and microglia; downregulate proinflammatory } \\
\text { cytokines; upregulate anti-inflammatory cytokines in the brain; inhibit the activation of GSK-3 } \beta \text { and reverse } \\
\text { neuroinflammatory-induced NF- } k B \text { activation signaling pathways; exert inhibitory effects on NALP3 } \\
\text { inflammasome, caspase- } 1 \text {, and IL-1 } 1 \beta \text {. }\end{array}$ & [75] \\
\hline Paeoniflorin & $\begin{array}{l}\text { Bilateral intrahippocampal injection of } A \beta 1-42 \text { in rats-i.p. } \\
\text { once daily for } 14 \text { days }\end{array}$ & $\begin{array}{l}\text { Increased the expressions of Nrf2, HO- } 1 \text { and } \gamma \text {-GCS mRNA; enhance the level of GSH and decrease the } \\
\text { contents of MDA and carbonyl protein in the hippocampus; improve the NAIP expression and reduce the } \\
\text { Caspase- } 3 \text { expression in the hippocampus neurons. }\end{array}$ & [76] \\
\hline Paeoniflorin & $\begin{array}{l}\text { A } \beta 1-42-\text { mediated neurotoxicity in rats }-7.5,15 \text { or } 30 \mathrm{mg} / \mathrm{kg} \text { i.p. } \\
\text { for } 20 \text { days }\end{array}$ & $\begin{array}{c}\text { Improve memory (dose dependent) in Morris water maze test; inhibit neuronal apoptosis; maintain } \\
\text { intracellular } \mathrm{Ca}^{2+} \text { homeostasis; increase GSH content; suppress NOS activity and NO level, decrease of } \\
\text { carbonyl protein and MDA levels. }\end{array}$ & [77] \\
\hline
\end{tabular}


A number of studies have targeted the oxidative stress and associated disorders by inducing the pathology with D-(+)-galactose injection into experimental animals. In this model, catalpol has been shown to reduce the level of $A \beta$ in the cerebral cortex along with improvement of learning and memory; while the level of antioxidant defenses (SOD and GPx) were boosted [58]. In senescent mice

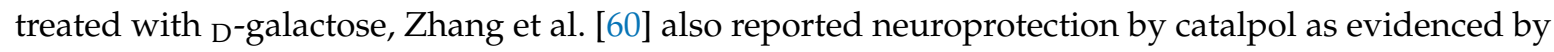
the increased level and activity of choline acetyltransferase (CHAT). Moreover, catalpol in this model has been shown to reverse the suppressed level of muscarinic acetylcholine (ACh) receptor M1 while concomitantly suppressing the level of inflammatory and oxidant markers (TNF- $\alpha$, IL-1 and advanced glycation end products (AGEs)) [60]. Improvement of memory deficit along with antioxidant markers (glutathione S-transferase (GSH-ST), glutamine synthetase (GS) and creatine kinase (CK) have also been shown for catalpol [61,63].

In other experiments, $A \beta$ was directly injected into the brain to study the biochemical and behavioral changes in animals. Catalpol was among the iridoids showing activity in this model where prevention of the ACh neuronal damage was noted from the increased level of choline CHAT positive cells density in cerebral cortex as well as increased level of ChAT activity [28]. Geniposide also ameliorated the $\mathrm{A} \beta$-induced neuronal abnormalities including cellular densities and synaptic proteins level in the transgenic mice model [63]. On the other hand, linalool has been shown to reverse cognitive deficits and altered the level of the antioxidant and protein (SOD, GPx, AChE) levels/activity in mice injected with $A \beta$ [69]. The effect of paeoniflorin in memory improvement and protection of animals from $A \beta$ through mechanisms including enhancing antioxidant defenses (e.g., GSH) and calcium homeostasis have also been reported [76,77].

Zhang et al. [62] employed the APP/PS1 Transgenic mouse model of AD to study the potential benefit of geniposide. The insulin deficiency induced by streptozotocin (STZ) in these wild-type transgenic animals appeared to enhance the GSK-3 $\beta$ level/activity which was suppressed by geniposide administration in a dose dependent manor. It is worth noting that the doses employed here were very small $(5,10$, and $20 \mathrm{mg} / \mathrm{kg})$. The data were also in line with the broader effect of geniposide in signal transduction pathways related to insulin resistance reviewed recently [17]. The GSK-3 $\beta$ plays direct role in $\tau$ protein hyperphosphorylation $[86,87]$. The role of the Akt in the regulation of GSK-3 $\beta$ is also well understood and its phosphorylation initiates its inactivation that appeared to be modulated by geniposide. In agreement with this data, geniposide can also regulate the phosphorylation of $\tau$ protein both in the insulin-dependent and independent manor in primary cultured cortical neurons [63]. It does also enhance the phosphorylation of Akt at Ser473 and Thr308 sites [63]. The dual effect of geniposide both in diabetes and $\mathrm{AD}$ is thus evident from its effect on the phosphorylation of $\tau$ protein via the PI3K-GSK-3 $\beta$ kinase pathway. To date, hyperphosphorylated $\tau$ protein is one of the pathological hallmark of $\mathrm{AD}$ as it is the principal component of neurofibrillary tangles (NFTs) [87]. The structural integrity of $\tau$ protein is regulated by a cascade of phosphorylation-related pathways, and hence both kinases and phosphatases play important roles in stable NFT formation. The GSK-3 $\beta$ being the key player in the kinase-mediated hyperphosphorylation of $\tau$ protein, its regulation by geniposide seems to shed some light into the possible mechanism of iridoids' action. The crosstalk between diabetes and AD was also highlighted by Gao et al. [67] who confirmed the potential role of geniposide through GSK-3 $\beta$ regulation. Similarly, in the study by Liu et al. [68], geniposide has been shown to decrease the $A \beta 1-42$ level while improving the expression of IDE in A $\beta$-treated STZ-induced diabetic rats. In the further experiment on transgenic mice model, geniposide was shown to improve learning and memory along with antiinflammatory effect (through suppression of RAGE-dependent signaling in activation of ERK and IKB/NF- $\mathrm{kB}$ and the production of TNF- $\alpha$, IL-1 $\beta$ ) and lowering the A $\beta$ level in the cerebrum [65]. Other compounds which have been shown to improve learning and memory in transgenic model of AD include linalool that could suppress pro-inflammatory proteins such as p38 MAPK, NOS-2, cyclooxygenase-2 (COX2) and IL-1 $\beta$ [70]. The effect of paeoniflorin in the transgenic mouse model of AD was also studied by $\mathrm{Gu}$ et al. [75]. In addition to improvement of the memory deficit, a reduction in the level of inflammation (NF-KB, TNF- $\alpha$, IL-1 $\beta$, IL-6) and apoptotic (caspase-3) 
markers were observed. As demonstrated for geniposide (above), paeoniflorin also modulate the GSK-3 $\beta$ signaling in transgenic animal model of AD [75].

Other behavioral models of AD included the scopolamine-induced AD model where loganin showed beneficial effect through the route of administration [71]. The neuroprotective effect of monoterpenes in other in vivo models has also been documented. For example, oleuropein could ameliorate the pentylenetetrazole (PTZ)-induced seizures in mice or colchicine-induced learning and memory deficits [73].

\section{Insights into the Mechanism of Action of Iridoids and Other Monoterpenes in AD}

The previous sections on the in vitro and in vivo effects of monoterpenes provided a plethora of evidences linking these compounds with key pathological pathways of AD. The general mechanism of action of monoterpenes in the AD brain is depicted in Figure 4. Some of the key features of monoterpenes, particularly iridoids, as an emerging class of compounds as anti-AD agents are shown below.

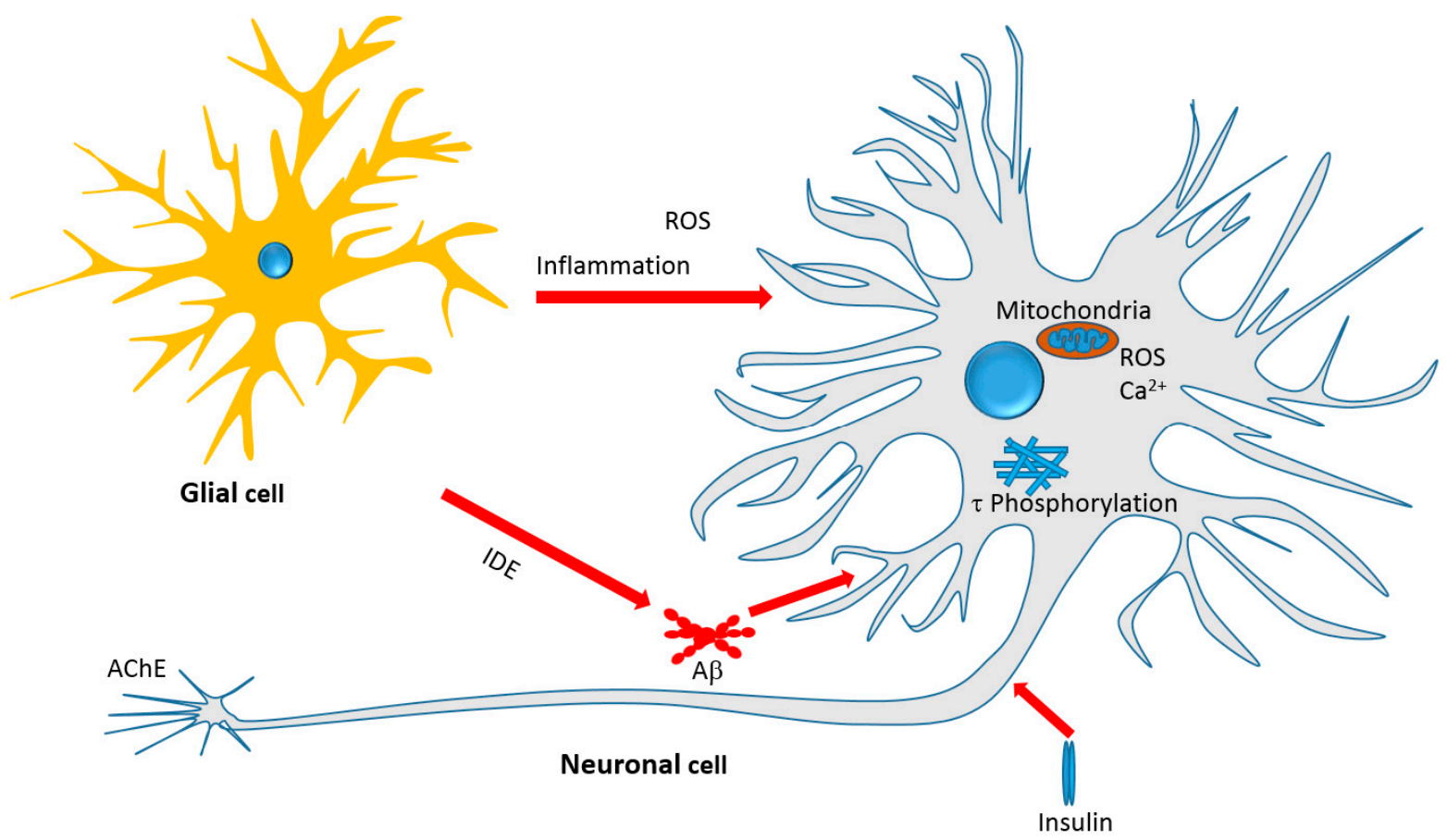

Figure 4. Therapeutic targets of iridoids and other monoterpenes discussed in this review. Antiinflammatory effect, amelioration of oxidative stress, mechanisms related to A $\beta$ formation, aggregation and clearance, $\tau$-protein phosphorylation and aggregation, and neurotoxicity associated with mitochondrial dependent and independent mechanisms are among the therapeutic targets.

The role of $\mathrm{A} \beta$ in the pathology and as therapeutic target for $\mathrm{AD}$ has been reviewed in the various literatures (e.g., [88-90]). Recent review articles from our laboratories have also shown that many polyphenolic compounds such the flavonoids, diterpenoids and cinamate derivatives display therapeutic potential for AD through multiple mechanisms involving $A \beta$ [6-14]. Hence, the formation, aggregation and toxicity of $A \beta$ can all serve as targets for therapeutic agents. The direct role of monoterpenes in the formation and aggregation of $A \beta$ is however less clear and the observed activity at moderate concentration may not be of a high degree of therapeutic relevance. Never the less, direct effect on APP processing enzymes has been shown. The predominant forms of the pathological A $\beta$ in the brain are $A \beta 1-40$ and to a lesser extent $A \beta 1-42$ which are formed through the amyloidgenic $\beta$-secretase-dependent pathway. The selective inhibition of this enzyme by monoterpenes (Table 1 ) without much effect on the non-amyloidogenic marker enzyme ( $\alpha$-secretase) is an interesting finding. 
A large body of evidence also suggests that monoterpenes (Tables 1 and 2) ameliorate the A $\beta$-induced cytotoxicity both in cultured neuronal cells and various animal models of AD [6-14]. Upon aggregation, the $A \beta$ oligomers induce neurotoxicity leading to cell death, impairment of synaptic function and behavioral deficits that are commonly observed in AD animal models. Hence, one major target of the iridoids as well as the selected other monoterpenes appear to be mediated through mechanisms related to $A \beta$ formation and/or toxicity.

The role of ROS in A $\beta$-induced neurotoxicity has been well established from evidences mostly linking redox metals like copper, zinc, and iron coordinating the generation of toxic free radicals and/or ROS [91-97]. As inhibitors of ROS generation through direct metal chelation and ROS scavenging, the role of polyphenols as potential therapeutic agents for AD has been extensively studied. In this direction, our own studies on catechol functional group and the flavonoid skeleton as optimized structural moieties for biological effects have been exhaustively researched [98-115]. The monoterpenes presented in this communication however lack such structural moiety unless additional skeleton as that shown in oleuropein is added (Figure 3). Their effect on the amelioration of the A $\beta$-toxicity as well as neurotoxicity induced by $\mathrm{H}_{2} \mathrm{O}_{2}$ suggest a mechanism of action beyond direct ROS scavenging. This can include boosting antioxidant defenses, and in this connection, numerous studies have shown an increased antioxidant status in the AD brain following treatment by monoterpenes (Table 2).

Another well-defined mechanism of action of monoterpenes in the AD brain appears to be linked to anti-inflammatory effect. In view of neuroinflammation as the major pathological hallmark of $\mathrm{AD}$, the role of inflammatory cells activation in the brain, primarily astrocyte and microglial cells, have been investigated in the last few decades. Readers are thus directed to excellent reviews in the field [116-122]. Interestingly, all of the best-characterised inflammatory markers such as TNF, IL-1, COX and NOS have been shown to be suppressed by the studied compounds in this review. Since inhibition of these proinflammatory cytokines such TNF is known to provide favorable outcome in AD [123,124], the suppressive effect of numerous monoterpenes on proinflammatory level in the Alzheimer's brain is in line with potential benefit in AD. Among the regulators of cytokines in their proinflammatory effect is the NF- $\kappa$ B which has been demonstrated to play key role in AD [125]. As modulators of the NF- $k B$, monoterpenes appear to also link their potential therapeutic mechanism through such an effect.

Leptin is one of the hormones produced by adipocytes with primary function in body weight and fat regulation through diverse mechanisms including modulation of food intake and metabolism [126]. Diverse other functions of leptin were however emerging in recent years; these include modulation of the immune response and broad range of neuronal regulation from neuroprotection to cognition $[127,128]$. The role of leptin receptor-mediated regulation in the cerebral cortex and hippocampus and dysregulation in AD has also been well recognized [129-132]. In addition to neurons, immune cells in the brain such as astrocytes and glial cells do also express leptin receptors and are regulated by this adipocytes' hormone [133,134]. Considering evidences showing the potential neuroprotective effect of leptin under pathological condition as well as many other in vitro and in vivo experiments (e.g., [135-137]), the modulatory effects of monoterpenes in this system is an exciting development. As leptin antagonist abolished the effect of geniposide on $\tau$ phosphorylation and phosphorylation of Akt at Ser-473 site and GSK-3 $\beta$ at Ser-9 in the Alzheimer's brain (Table 1), part of the iridoids action is likely to be mediated through leptin regulation.

As with their formation, the degradation of $A \beta$ peptides and plaques must be tightly regulated to avoid pathological disorders such the AD. Among the various mechanisms involved in $A \beta$ degradation and clearance include the $\mathrm{A} \beta$ proteases, low-density lipoprotein receptor-related protein 1 , and the apolipoprotein E systems [138]. Of the protease enzymes, neprilysin (also known as membrane metallo-endopeptidase) is a zinc-dependent metalloprotease that cleaves $\mathrm{A} \beta$ and have shown a good correlation with $A \beta$ accumulation [139]. The endothelin-converting enzyme, and angiotensin-converting enzyme do also function as $\mathrm{A} \beta$ degrading enzymes. The role of IDE in A $\beta$ degradation has recently been clarified and its dysregulation is now known to contribute to the pathology of the AD $[138,140,141]$. In fact, IDE is considered to be the main extracellular protease 
enzyme for the degradation of $A \beta[142,143]$ and its expression, as with neprilysin, in the hippocampus has been shown to decrease with increasing age [144]. Hence, upregulation of the $A \beta$ degrading enzymes is among the therapeutic approaches for AD [145-147]. In the brain, glial cells such as the microglia and astrocytes are the main source of IDE secretion [113] and their dysregulation could thus contribute to AD pathology; while promotion of IDE secretion from these cells could be implicated in $\mathrm{AD}$ therapy through enhancing $\mathrm{A} \beta$ clearance. The astrocytes and microglial cells are also primary phagocytes in the brain that recognize $A \beta$ through membrane receptors to remove through phagocytosis [148]. The therapeutic approach of AD by upregulating IDE is however a tricky one, as IDE also selectively degrades insulin and its inhibitors are needed to improve glucose homeostasis (e.g., in diabetes). The role of iridoids in this regards is very interesting as geniposide has been shown to upregulate IDE [39] while displaying potent antidiabetic effect [17]. As IDE is degrading the monomeric form of $A \beta$, it is preventing the formation of oligomers or aggregates that is prerequisite to $A \beta$ cytotoxicity in neuronal cells. Hence, a clear line of evidence is now available for geniposide and/or other iridoids that showed a promise in the Alzheimer's brain.

The dual effect of iridoids in diabetes and AD is also manifested from the possible mechanism of action related to the $\tau$ protein phosphorylation pathway. The formation of intracellular NFTs is a result of aggregation of the hyperphosphorylated $\tau$-protein. As a major component of the neuronal cytoskeleton, $\tau$-protein is closely associated with microtubules and aids a number of neuronal functions from axonal transport to neurite outgrowth $[87,149]$. The function of $\tau$ protein in stabilizing the microtubule to facilitate the normal neuronal function is governed by its phosphorylation which is regulated by a number of cellular kinases and phosphatases [150]. Consequently, $\tau$ protein dysregulation is among the pathological hallmark of AD as in NFTs and hence serves as a target for drug therapy. Hyperphosphorylation of $\tau$-protein quickly initiates the formation of helical filaments and aggregates as seen in the NFTs of AD. This intern leads to microtubule disassembly and destabilization [151]. The signaling cascade in $\tau$-protein hyperphosphorylation has been shown to involve the GSK-3 $\beta$ that directly act on the protein (to phosphorylate it) and make it to disassociate with the microtubules $[152,153]$. Hence, downregulating GSK-3 $\beta$ by drugs is essential in AD not only to regulate $\tau$-protein hyperphosphorylation but also to manage other deleterious effect of GSK- $3 \beta$ such as in ROS generation from the mitochondria. For example, GSK-3 $\beta$ has been shown to down-regulate the transcription factor Nrf2 after oxidative damage [154]. The GSK-3 $\beta$ itself is regulated by other kinases such as the Akt that phosphorylate GSK-3 $\beta$ at different sites to negatively regulate its activity. Furthermore, activation of PI3K triggers the activation of Akt that phosphorylates GSK-3 $\beta$ leading to inhibition of $\tau$-protein phosphorylation. Hence, the dysfunction of PI3K/Akt signaling is linked to $\tau$-protein phosphorylation or NFT formation in AD. The p38 MAPK is also emerged as anther kinase involved in $\tau$-protein phosphorylation and hence can be targeted by drugs [155-157]. A review article of such signal transduction pathways and possible pharmacological regulations is eloquently presented by Medina et al. [158]. The observation of iridoids to regulate $\tau$-protein phosphorylation by inhibiting GSK-3 $\beta$ and regulation of the associated system primarily the PI3K/Akt signaling (Tables 1 and 2) is a remarkable documentation of record for this group of compounds. The pioneering compound in this regard is geniposide (e.g., [38,39,67]). Other natural products such phenolics including resveratrol [159], curcumin [160], hyperforin [161] and capsaicin [162] have been shown to display inhibitory effect against $\tau$ protein hyperphosphorylation as well as affect in vivo models of AD. Hence, iridoids with structural feature distinctively different from polyphenols appear to share one common feature of mechanism in their potential AD modulations.

Overall, it appears that the iridoids and some other monoterpenoids target the various cellular and biochemical features of AD pathology depicted in Figure 4. They target oxidative stress by boosting antioxidant defenses; inhibit the $\mathrm{A} \beta$ cascades particularly neurotoxicity; inhibit $\tau$-protein phosphorylation and hence NFTs formation; promote the clearance of toxic proteins (A $\beta$ ) through IDE; modulate the insulin signaling pathway and insulin resistance as antidiabetic agents; and display a range of anti-inflammatory effects by suppressing the expression of numerous key proinflammatory 
proteins. Another interesting development is the direct effect of monoterpenes on AChE enzyme and further possible opportunity of potency optimization through chemical synthesis.

\section{Drug-Likeness and Structural Perspectives}

A range of qualitative and quantitative measures of drug-likeness parameters have been employed in recent years to identify leads in drug discovery researches as well as improving the efficiency of known bioactive compounds. In the in silico drug-likeness predictions, the undesirable properties of small molecular weight compounds assessed by poor ADMET (absorption, distribution, metabolism, excretion, and toxicity) characteristics are used as a screening tool [163]. In this regard, monoterpenes (unless glycosylated, see Figure 3) act as a component of essential oils with list solubility profile in water falls within the poor drug-likeness profile. Accordingly, their absorption, distribution, metabolism, and excretion profiles were not in line with what one expects as ideal drug molecules. Hence, all in vitro and in vivo data so far suggest that they are absorbed and distributed to tissues but with far slower rate than that ideally expected [164-168]. Human trial also confirmed these observations but the iridoid glycosides, with sugar attachment thereby increasing their polarity, appear to be a good compromise in vivo [169-173]. Like many other sugar-linked natural products, the iridoid glycosides such as geniposide have been shown to be metabolized by intestinal bacteria to release their aglycone (e.g., genipin) $[174,175]$ which also give rise to conjugated products (e.g., with glucuronic acid) [176]. Increasing water solubility by glycosylation to release a bioactive aglycone in the intestine has been reported to be one way of enhancing bioavailability for natural products [177]. Even for glycosides such as geniposide, however, the absolute oral bioavailability after oral administration remains to be poor $\sim 9.67 \%$ [178]. Nevertheless, both in vitro and in vivo experiments have shown good effects in ameliorating the biochemical and behavioral markers of AD. Hence, despite their predicted poor drug-likeness profile, iridoids and other monoterpenes have shown potent activity to be seriously considered as potential lead compounds in future studies.

\section{Future Prospects}

One common advantage of employing compounds of natural origin (e.g., monoterpenes) is that they are associated with common foods and beverages that are already in use for human consumption. As neuromodulators, particularly in $\mathrm{AD}$, the beneficial effects of some essential oils as crude mixtures of small molecular weight fragrant compounds including monoterpenes have been reported in the various literature [see review article, 179]. As indicated in the preceding section, however, the drug likeness of these molecules has not been in favor of their development as drugs given their poor water solubility and bioavailability. The iridoids glycosides appear to offer a better bioavailability profile and pharmacology as evidenced from their activity profile in vitro and in vivo. The fact that both the glycosylated and the aglycones are active in vitro suggests that the glycosides being a better bioavailable compounds could be more preferable as drug candidates. One should bear in mind that research on this class of compounds is still at its infant stage and more work is needed on optimization of their pharmacology through medicinal chemistry. The effect of some monoterpenes, for example, could be enhanced by over 100-fold when other functional groups such as a carbamate moiety were added or they being incorporated into the existing anti-AD drugs such as galantamine $[27,51]$. Naturally, human clinical trials would offer not only valuable data on efficacy but also pharmacokinetic profile that are desperately needed for these compounds. Such study of course would be preferred once a lead compound is identified and optimized through future research. In the meantime, all the available data now suggest that small molecules of the iridoids class and related monoterpenes could be considered as potential leads for AD therapy.

Conflicts of Interest: The author declare no conflict of interest. No funding from internal or external sources were used for this contribution. 


\section{References}

1. Alzheimer's Association. Alzheimer's Disease Facts and Figures. Available online: https://www.alz.org/ facts / (accessed on 22 December 2017).

2. Alzheimer's Disease International. World Alzheimer Report 2016, Improving Healthcare for People Living with Dementia: Coverage, Quality and Costs Now and in the Future. Available online: https:/ /www.alz.co. uk/research/world-report-2016 (accessed on 22 December 2017).

3. Jost, B.C.; Grossberg, G.T. The natural history of Alzheimer's disease: A brain bank study. J. Am. Geriatr. Soc. 1995, 43, 1248-1255. [CrossRef] [PubMed]

4. Haas, C. Strategies, development, and pitfalls of therapeutic options for Alzheimer's disease. J. Alzheimers Dis. 2012, 28, 241-281. [CrossRef] [PubMed]

5. Moreira, P.I.; Zhu, X.; Nunomura, A.; Smith, M.A.; Perry, G. Therapeutic options in Alzheimer's disease. Expert Rev. Neurother. 2006, 6, 897-910. [CrossRef] [PubMed]

6. Elufioye, T.O.; Berida, T.I.; Habtemariam, S. Plants-derived neuroprotective agents: Cutting the cycle of cell death through multiple mechanisms. eCAM 2017, 2017, 3574012. [CrossRef] [PubMed]

7. Braidy, N.; Behzad, S.; Habtemariam, S.; Ahmed, T.; Daglia, M.; Nabavi, S.M.; Sobarzo-Sanchez, E.; Nabavi, S.F. Neuroprotective effects of citrus fruit-derived flavonoids, nobiletin and tangeretin in Alzheimer's and Parkinson's disease. CNS Neurol. Disord. Drug Targets 2016, 16, 387-397. [CrossRef] [PubMed]

8. Habtemariam, S. Rutin as a natural therapy for Alzheimer's disease: Insights into its mechanisms of action. Curr. Med. Chem. 2016, 23, 860-873. [CrossRef] [PubMed]

9. Habtemariam, S.; Lentini, G. The therapeutic potential of rutin for diabetes: An update. Mini Rev. Med. Chem. 2015, 15, 524-528. [CrossRef] [PubMed]

10. Nabavi, S.F.; Khan, H.; D’onofrio, G.; Šamec, D.; Shirooie, S.; Dehpour, A.R.; Castilla, S.A.; Habtemariam, S.; Sobarzo-Sanchez, E. Apigenin as neuroprotective agent: Of mice and men. Pharmacol. Res. 2017, in press. [CrossRef] [PubMed]

11. Nabavi, S.F.; Braidy, N.; Habtemariam, S.; Sureda, A.; Manayi, A.; Nabavi, S.M. Neuroprotective effects of fisetin in Alzheimer's and Parkinson's Diseases: From chemistry to medicine. Curr. Top. Med. Chem. 2016, 16, 1910-1915. [CrossRef] [PubMed]

12. Nabavi, S.F.; Braidy, N.; Habtemariam, S.; Orhan, I.E.; Daglia, M.; Manayi, A.; Gortzi, O.; Nabavi, S.M. Neuroprotective effects of chrysin: From chemistry to medicine. Neurochem. Int. 2015, 90, 224-231. [CrossRef] [PubMed]

13. Habtemariam, S. Protective effects of caffeic acid and the Alzheimer's brain: An update. Mini Rev. Med. Chem. 2017, 17, 667-674. [CrossRef] [PubMed]

14. Habtemariam, S. The therapeutic potential of rosemary (Rosmarinus officinalis) diterpenes for Alzheimer's disease. eCAM 2016, 2016, 2680409. [CrossRef] [PubMed]

15. Tholl, D. Biosynthesis and biological functions of terpenoids in plants. Adv. Biochem. Eng. Biotechnol. 2015, 148, 63-106. [CrossRef] [PubMed]

16. Dewick, P.M. The biosynthesis of C5-C25 terpenoid compounds. Nat. Prod. Rep. 2002, 19, 181-222. [CrossRef] [PubMed]

17. Habtemariam, S. Antidiabetic potential of monoterpenes: A case of small molecules punching above their weight. Int. J. Mol. Sci. 2018, 19, 4. [CrossRef] [PubMed]

18. Pichersky, E.; Raguso, R.A. Why do plants produce so many terpenoid compounds? New Phytol. 2016. [CrossRef] [PubMed]

19. Llusià, J.; Estiarte, M.; Peñuelas, J. Terpenoids and plant communication. Butll. Inst. Catalana Hist. Nat. 1996, 64, 125-133.

20. Singh, B.; Sharma, R.A. Plant terpenes: Defense responses, phylogenetic analysis, regulation and clinical applications. Biotech 2015, 5, 129-151. [CrossRef] [PubMed]

21. Biere, A.; Marak, H.B.; van Damme, J.M. Plant chemical defense against herbivores and pathogens: Generalized defense or trade-offs? Oecologia 2004, 140, 430-441. [CrossRef] [PubMed]

22. Reudler, J.H.; Lindstedt, C.; Pakkanen, H.; Lehtinen, I.; Mappes, J. Costs and benefits of plant allelochemicals in herbivore diet in a multi enemy world. Oecologia 2015, 179, 1147-1158. [CrossRef] [PubMed]

23. Mason, P.A.; Deane-Bowers, M. Localization of defensive chemicals in two congeneric butterflies (Euphydryas, Nymphalidae). J. Chem. Ecol. 2017, 43, 480-486. [CrossRef] [PubMed] 
24. Laurentz, M.; Reudler, J.H.; Mappes, J.; Friman, V.; Ikonen, S.; Lindstedt, C. Diet quality can play a critical role in defense efficacy against parasitoids and pathogens in the Glanville fritillary (Melitaea cinxia). J. Chem. Ecol. 2012, 2012, 116-125. [CrossRef] [PubMed]

25. Wahlberg, N. The phylogenetics and biochemistry of host-plant specialization in Melitaeine butterflies (Lepidoptera: Nymphalidae). Evolution 2001, 55, 522-537. [CrossRef]

26. Marumoto, S.; Okuno, Y.; Miyazawa, M. Inhibition of $\beta$-Secretase activity by monoterpenes, sesquiterpenes, and C13 norisoprenoids. J. Oleo Sci. 2017, 66, 851-855. [CrossRef] [PubMed]

27. Stavrakov, G.; Philipova, I.; Zheleva-Dimitrova, D.; Valkova, I.; Salamanova, E.; Konstantinov, S.; Doytchinova, I. Docking-based design and synthesis of galantamine-camphane hybrids as inhibitors of acetylcholinesterase. Chem. Biol. Drug Des. 2017, 90, 709-718. [CrossRef] [PubMed]

28. Wang, J.H.; Xie, H.; Zhao, T.K.; Kang, B. Catalpol regulates cholinergic nerve system function through effect on choline acetyl-transferase not M receptor affinity. Biomed. Pharmacother. 2015, 69, 291-296. [CrossRef] [PubMed]

29. Bi, J.; Jiang, B.; Liu, J.H.; Lei, C.; Zhang, X.L.; An, L.J. Protective effects of catalpol against $\mathrm{H}_{2} \mathrm{O}_{2}$-induced oxidative stress in astrocytes primary cultures. Neurosci. Lett. 2008, 442, 224-227. [CrossRef] [PubMed]

30. Wang, J.H.; Sun, Q.X.; Xia, Z.Q.; Hu, Y.E. Regulatory effect of catalpol from Radix Rehmanniae on M2 receptor density in M2 receptor transfected CHO cells. Chin. Pharmacol. Bull. 2006, 22, 1462-1466.

31. Hur, J.; Pak, S.C.; Koo, B.S.; Jeon, S. Borneol alleviates oxidative stress via upregulation of Nrf2 and Bcl-2 in SH-SY5Y cells. Pharm. Biol. 2013, 51, 30-35. [CrossRef] [PubMed]

32. Khan, A.; Vaibhav, K.; Javed, H.; Tabassum, R.; Ahmed, M.E.; Khan, M.M.; Khan, M.B.; Shrivastava, P.; Islam, F.; Siddiqui, M.S.; et al. 1,8-cineole (eucalyptol) mitigates inflammation in amyloid beta toxicated PC12 cells: Relevance to Alzheimer's disease. Neurochem. Res. 2014, 39, 344-352. [CrossRef] [PubMed]

33. Porres-Martínez, M.; González-Burgos, E.; Carretero, M.E.; Gómez-Serranillos, M.P. In vitro neuroprotective potential of the monoterpenes $\alpha$-pinene and 1,8-cineole against $\mathrm{H}_{2} \mathrm{O}_{2}$-induced oxidative stress in PC12 cells. Z. Naturforsch. C. 2016, 71, 191-199. [CrossRef] [PubMed]

34. Yamazaki, M.; Sakura, N.; Chiba, K.; Mohri, T. Prevention of the neurotoxicity of the amyloid beta protein by genipin. Biol. Pharm. Bull. 2001, 24, 1454-1455. [CrossRef] [PubMed]

35. Nam, K.N.; Choi, Y.S.; Jung, H.J.; Park, G.H.; Park, J.M.; Moon, S.K.; Cho, K.H.; Kang, C.; Kang, I.; Oh, M.S.; et al. Genipin inhibits the inflammatory response of rat brain microglial cells. Int. Immunopharmacol. 2010, 10, 493-499. [CrossRef] [PubMed]

36. Yamazaki, M.; Chiba, K.; Yoshikawa, C. Genipin suppresses A23187-induced cytotoxicity in neuro2a cells. Biol. Pharm. Bull. 2009, 32, 1043-1046. [CrossRef] [PubMed]

37. Zhao, C.; Lv, C.; Li, H.; Du, S.; Liu, X.; Li, Z.; Xin, W.; Zhang, W. Geniposide protects primary cortical neurons against oligomeric A $\beta 1-42$-induced neurotoxicity through a mitochondrial pathway. PLoS ONE 2016, 11, e0152551. [CrossRef] [PubMed]

38. Liu, J.; Liu, Z.; Zhang, Y.; Yin, F. Leptin signaling plays a critical role in the geniposide-induced decrease of tau phosphorylation. Acta Biochim. Biophys. Sin. 2015, 47, 1018-1022. [CrossRef] [PubMed]

39. Zhang, Y.; Xia, Z.; Liu, J.; Yin, F. Cell signaling mechanisms by which geniposide regulates insulin-degrading enzyme expression in primary cortical neurons. CNS Neurol. Disord. Drug Targets 2015, 14, 370-377. [CrossRef] [PubMed]

40. Liu, Z.; Zhang, Y.; Liu, J.; Yin, F. Geniposide attenuates the level of $A \beta_{1-42}$ via enhancing leptin signaling in cellular and APP/PS1 transgenic mice. Arch. Pharm. Res. 2017, 40, 571-578. [CrossRef] [PubMed]

41. Sun, P.; Ding, H.; Liang, M.; Li, X.; Mo, W.; Wang, X.; Liu, Y.; He, R.; Hua, Q. Neuroprotective effects of geniposide in SH-SY5Y cells and primary hippocampal neurons exposed to A $\beta 42$. Biomed. Res. Int. 2014, 2014, 284314. [CrossRef] [PubMed]

42. Sun, P.; Chen, J.Y.; Li, J.; Sun, M.R.; Mo, W.C.; Liu, K.L.; Meng, Y.Y.; Liu, Y.; Wang, F.; He, R.Q.; et al. The protective effect of geniposide on human neuroblastoma cells in the presence of formaldehyde. BMC Complement. Altern. Med. 2013, 13, 152. [CrossRef] [PubMed]

43. Liu, H.J.; Yin, F.; Guo, L.X.; Deng, X.H.; Hu, Y.H. Neuroprotection of geniposide against hydrogen peroxide induced PC12 cells injury: Involvement of PI3 kinase signal pathway. Acta Pharmacol. Sin. 2009, 30, 159-165. [CrossRef] [PubMed]

44. Liu, J.; Yin, F.; Zheng, X.; Jing, J.; Hu, Y. Geniposide, a novel agonist for GLP-1 receptor, prevents PC12 cells from oxidative damage via MAP kinase pathway. Neurochem. Int. 2007, 51, 361-369. [CrossRef] [PubMed] 
45. Hwang, E.-S.; Kim, H.-B.; Lee, S.; Kim, M.-J.; Lee, S.-O.; Han, S.-M.; Maeng, S.; Park, J.-H. Loganin enhances long-term potentiation and recovers scopolamine-induced learning and memory impairments. Physiol. Behav. 2017, 171, 243-248. [CrossRef] [PubMed]

46. Bhakta, H.K.; Park, C.H.; Yokozawa, T.; Min, B.S.; Jung, H.A.; Choi, J.S. Kinetics and molecular docking studies of loganin, morroniside and 7-O-galloyl-D-sedoheptulose derived from Corni fructus as cholinesterase and $\beta$-secretase 1 inhibitors. Arch. Pharm. Res. 2016, 39, 794-805. [CrossRef] [PubMed]

47. Kim, H.; Youn, K.; Ahn, M.R.; Kim, O.Y.; Jeong, W.S.; Ho, C.T.; Jun, M. Neuroprotective effect of loganin against A $\beta 25-35$-induced injury via the NF- $\mathrm{BB}-$ dependent signaling pathway in PC12 cells. Food Funct. 2015, 6, 1108-1116. [CrossRef] [PubMed]

48. Wan, Y.Y.; Wang, C.F.; Wang, Q.H.; Xiao, Y.; Wang, Z.B.; Kuang, H.X. Study on active constituents against Alzheimer's disease from Valeriana amurensis. Zhongguo Zhong Yao Za Zhi. 2016, 41, 1649-1653. [CrossRef] [PubMed]

49. Youn, K.; Jeong, W.S.; Jun, M. $\beta$-Secretase (BACE1) inhibitory property of loganin isolated from Corni fructus. Nat. Prod. Res. 2013, 27, 1471-1474. [CrossRef] [PubMed]

50. Kaufmann, D.; Dogra, A.K.; Wink, M. Myrtenal inhibits acetylcholinesterase, a known Alzheimer target. J. Pharm. Pharmacol. 2011, 63, 1368-1371. [CrossRef] [PubMed]

51. Kurt, B.Z.; Gazioglu, I.; Dag, A.; Salmas, R.E.; Kayık, G.; Durdagi, S.; Sonmez, F. Synthesis, anticholinesterase activity and molecular modelling study of novel carbamate-substituted thymol/carvacrol derivatives. Bioorg. Med. Chem. 2017, 25, 1352-1363. [CrossRef] [PubMed]

52. Liu, L.; Wang, S.Y.; Wang, J.G. Role of PI3K/Akt pathway in effect of paeoniflorin against A $\beta 25-35$-induced PC12 cell injury. Zhongguo Zhong Yao Za Zhi 2014, 39, 4045-4049. [PubMed]

53. Dong, H.; Li, R.; Yu, C.; Xu, T.; Zhang, X.; Dong, M. Paeoniflorin inhibition of 6-hydroxydopamine-induced apoptosis in PC12 cells via suppressing reactive oxygen species-mediated PKC $\delta / N F-\kappa B$ pathway. Neuroscience 2015, 285, 70-80. [CrossRef] [PubMed]

54. Li, J.; Ji, X.; Zhang, J.; Shi, G.; Zhu, X.; Wang, K. Paeoniflorin attenuates A 325 -35-induced neurotoxicity in PC12 cells by preventing mitochondrial dysfunction. Folia Neuropathol. 2014, 52, 285-290. [CrossRef] [PubMed]

55. Wang, K.; Zhu, L.; Zhu, X.; Zhang, K.; Huang, B.; Zhang, J.; Zhang, Y.; Zhu, L.; Zhou, B.; Zhou, F. Protective effect of paeoniflorin on A $\beta 25-35$-induced SH-SY5Y cell injury by preventing mitochondrial dysfunction. Cell Mol. Neurobiol. 2014, 34, 227-234. [CrossRef] [PubMed]

56. Sun, R.; Wang, K.; Wu, D.; Li, X.; Ou, Y. Protective effect of paeoniflorin against glutamate-induced neurotoxicity in PC12 cells via Bcl-2/Bax signal pathway. Folia Neuropathol. 2012, 50, 270-276. [CrossRef] [PubMed]

57. Zhong, Z.; Wang, B.; Dai, M.; Sun, Y.; Sun, Q.; Yang, G.; Bian, L. Carvacrol alleviates cerebral edema by modulating AQP4 expression after intracerebral hemorrhage in mice. Neurosci. Lett. 2013, 555, 24-29. [CrossRef] [PubMed]

58. Huang, Z.; Wu, J.; Xiang, S.; Sheng, S.; Jiang, Y.; Yang, Z.; Hua, F. Catalpol preserves neural function and attenuates the pathology of Alzheimer's disease in mice. Mol. Med. Rep. 2016, 13, 491-496. [CrossRef] [PubMed]

59. Wang, J.H.; Li, W.T.; Yu, S.T.; Xie, H.; Han, H.R. Catalpol regulates function of hypothalamic-pituitaryadrenocortical-axis in an Alzheimer's disease rat model. Pharmazie 2014, 69, 688-693. [PubMed]

60. Zhang, X.; Jin, C.; Li, Y.; Guan, S.; Han, F.; Zhang, S. Catalpol improves cholinergic function and reduces inflammatory cytokines in the senescent mice induced by D-galactose. Food Chem. Toxicol. 2013, 58, 50-55. [CrossRef] [PubMed]

61. Zhang, X.L.; An, L.J.; Bao, Y.M.; Wang, J.Y.; Jiang, B. D-galactose administration induces memory loss and energy metabolism disturbance in mice: Protective effects of catalpol. Food Chem. Toxicol. 2008, 46, 2888-2894. [CrossRef] [PubMed]

62. Zhang, X.; Zhang, A.; Jiang, B.; Bao, Y.; Wang, J.; An, L. Further pharmacological evidence of the neuroprotective effect of catalpol from Rehmannia glutinosa. Phytomedicine 2008, 15, 484-490. [CrossRef] [PubMed]

63. Zhang, Y.; Yin, F.; Liu, J.; Liu, Z.; Guo, L.; Xia, Z.; Zidichouski, J. Geniposide attenuates insulin-deficiencyinduced acceleration of $\beta$-amyloidosis in an APP/PS1 transgenic model of Alzheimer's disease. Neurochem. Int. 2015, 89, 7-16. [CrossRef] [PubMed] 
64. Zhang, Y.; Yin, F.; Liu, J.; Liu, Z. Geniposide attenuates the phosphorylation of tau protein in cellular and insulin-deficient APP/PS1 transgenic mouse model of Alzheimer's disease. Chem. Biol. Drug Des. 2016, 87, 409-418. [CrossRef] [PubMed]

65. Lv, C.; Wang, L.; Liu, X.; Yan, S.; Yan, S.S.; Wang, Y.; Zhang, W. Multi-faced neuroprotective effects of geniposide depending on the RAGE-mediated signaling in an Alzheimer mouse model. Neuropharmacology 2015, 89, 175-184. [CrossRef] [PubMed]

66. Lv, C.; Liu, X.; Liu, H.; Chen, T.; Zhang, W. Geniposide attenuates mitochondrial dysfunction and memory deficits in APP/PS1 transgenic mice. Curr. Alzheimer Res. 2014, 11, 580-587. [CrossRef] [PubMed]

67. Gao, C.; Liu, Y.; Jiang, Y.; Ding, J.; Li, L. Geniposide ameliorates learning memory deficits, reduces tau phosphorylation and decreases apoptosis via GSK3 $\beta$ pathway in streptozotocin-induced Alzheimer rat model. Brain Pathol. 2014, 24, 261-269. [CrossRef] [PubMed]

68. Liu, J.; Zhang, Y.; Deng, X.; Yin, F. Geniposide decreases the level of A $\beta 1-42$ in the hippocampus of streptozotocin-induced diabetic rats. Acta Biochim. Biophys. Sin. 2013, 45, 787-791. [CrossRef] [PubMed]

69. Xu, P.; Wang, K.; Lu, C.; Dong, L.; Gao, L.; Yan, M.; Aibai, S.; Yang, Y.; Liu, X. Protective effects of linalool against amyloid beta-induced cognitive deficits and damages in mice. Life Sci. 2017, 174, 21-27. [CrossRef] [PubMed]

70. Sabogal-Guáqueta, A.M.; Osorio, E.; Cardona-Gómez, G.P. Linalool reverses neuropathological and behavioral impairments in old triple transgenic Alzheimer's mice. Neuropharmacology 2016, 102, 111-120. [CrossRef] [PubMed]

71. Kwon, S.H.; Kim, H.C.; Lee, S.Y.; Jang, C.G. Loganin improves learning and memory impairments induced by scopolamine in mice. Eur. J. Pharmacol. 2009, 619, 44-49. [CrossRef] [PubMed]

72. Rahimi, N.; Delfan, B.; Motamed-Gorji, N.; Dehpour, A.R. Effects of oleuropein on pentylenetetrazol-induced seizures in mice: Involvement of opioidergic and nitrergic systems. J. Nat. Med. 2017, 71, 389-396. [CrossRef] [PubMed]

73. Pourkhodadad, S.; Alirezaei, M.; Moghaddasi, M.; Ahmadvand, H.; Karami, M.; Delfan, B.; Khanipour, Z. Neuroprotective effects of oleuropein against cognitive dysfunction induced by colchicine in hippocampal CA1 area in rats. J. Physiol. Sci. 2016, 66, 397-405. [CrossRef] [PubMed]

74. Gu, X.; Cai, Z.; Cai, M.; Liu, K.; Liu, D.; Zhang, Q.; Tan, J.; Ma, Q. Protective effect of paeoniflorin on inflammation and apoptosis in the cerebral cortex of a transgenic mouse model of Alzheimer's disease. Mol. Med. Rep. 2016, 13, 2247-2252. [CrossRef] [PubMed]

75. Zhang, H.R.; Peng, J.H.; Cheng, X.B.; Shi, B.Z.; Zhang, M.Y.; Xu, R.X. Paeoniflorin attenuates amyloidogenesis and the inflammatory responses in a transgenic mouse model of Alzheimer's disease. Neurochem. Res. 2015, 40, 1583-1592. [CrossRef] [PubMed]

76. Zhong, S.Z.; Ma, S.P.; Hong, Z.Y. Peoniflorin activates Nrf2/ARE pathway to alleviate the A $\beta(1-42)$-induced hippocampal neuron injury in rats. Yao Xue Xue Bao 2013, 48, 1353-1357. [PubMed]

77. Zhong, S.Z.; Ge, Q.H.; Li, Q.; Qu, R.; Ma, S.P. Paeoniflorin attenuates A $\beta(1-42)$-mediated neurotoxicity by regulating calcium homeostasis and ameliorating oxidative stress in hippocampus of rats. J. Neurol. Sci. 2009, 280, 71-78. [CrossRef] [PubMed]

78. Ho, J.D.; Yeh, R.; Sandstrom, A.; Chorny, I.; Harries, W.E.; Robbins, R.A.; Miercke, L.J.; Stroud, R.M. Crystal structure of human aquaporin 4 at 1.8 A and its mechanism of conductance. Proc. Natl. Acad. Sci. USA 2009, 106, 7437-7442. [CrossRef] [PubMed]

79. Strand, L.; Moe, S.E.; Solbu, T.T.; Vaadal, M.; Holen, T. Roles of aquaporin-4 isoforms and amino acids in square array assembly. Biochemistry 2009, 48, 5785-5793. [CrossRef] [PubMed]

80. Moe, S.E.; Sorbo, J.G.; Sogaard, R.; Zeuthen, T.; Petter, O.O.; Holen, T. New isoforms of rat Aquaporin-4. Genomics 2008, 91, 367-377. [CrossRef] [PubMed]

81. Potokar, M.; Stenovec, M.; Jorgacevski, J.; Holen, T.; Kreft, M.; Ottersen, O.P.; Zorec, R. Regulation of AQP4 surface expression via vesicle mobility in astrocytes. Glia 2013, 61, 917-928. [CrossRef] [PubMed]

82. Verkman, A.S.; Smith, A.J.; Phuan, P.W.; Tradtrantip, L.; Anderson, M.O. The aquaporin-4 water channel as a potential drug target in neurological disorders. Expert. Opin. Ther. Targets 2017, 21, 1161-1170. [CrossRef] [PubMed]

83. Vella, J.; Zammit, C.; Giovanni, G.D.; Muscat, R.; Valentino, M. The central role of aquaporins in the pathophysiology of ischemic stroke. Front. Cell Neurosci. 2015, 9, 108. [CrossRef] [PubMed] 
84. Fukuda, A.M.; Badaut, J. Aquaporin 4: A player in cerebral edema and neuroinflammation. J. Neuroinflamm. 2012, 9, 279. [CrossRef] [PubMed]

85. Badaut, J.; Fukuda, A.M.; Jullienne, A.; Petry, K.G. Aquaporin and brain diseases. Biochim. Biophys. Acta 2014, 1840, 1554-1565. [CrossRef] [PubMed]

86. Balaraman, Y.; Limaye, A.R.; Levey, A.I.; Srinivasan, S. Glycogen synthase kinase $3 \beta$ and Alzheimer's disease: Pathophysiological and therapeutic significance. Cell Mol. Life Sci. 2006, 63, 1226-1235. [CrossRef] [PubMed]

87. Oliveira, J.; Costa, M.; de Almeida, M.S.C.; da Cruz E Silva, O.A.B.; Henriques, A.G. Protein phosphorylation is a key mechanism in Alzheimer's disease. J. Alzheimers Dis. 2017, 58, 953-978. [CrossRef] [PubMed]

88. León, R.; Garcia, A.G.; Marco-Contelles, J. Recent advances in the multitarget-directed ligands approach for the treatment of Alzheimer's disease. Med. Res. Rev. 2013, 33, 139-189. [CrossRef] [PubMed]

89. Ryan, T.M.; Roberts, B.R.; Streltsov, V.A.; Nuttall, S.D.; Masters, C.L. The role of A $\beta$ in Alzheimer's disease. In Amyloid Fibrils and Prefibrillar Aggregates: Molecular and Biological Properties; Otzen, D.E., Ed.; John Wiley \& Sons: Hoboken, NJ, USA, 2013; pp. 263-293. [CrossRef]

90. Salomone, S.; Caraci, F.; Leggio, G.M.; Fedotova, J.; Drago, F. New pharmacological strategies for treatment of Alzheimer's disease: Focus on disease modifying drugs. Br. J. Clin. Pharmacol. 2012, 73, 504-517. [CrossRef] [PubMed]

91. Bousejra-ElGarah, F.; Bijani, C.; Coppel, Y.; Faller, P.; Hureau, C. Iron(II) binding to amyloid- $\beta$, the Alzheimer's peptide. Inorg. Chem. 2011, 50, 9024-9030. [CrossRef] [PubMed]

92. Tahmasebinia, F.; Emadi, S. Effect of metal chelators on the aggregation of beta-amyloid peptides in the presence of copper and iron. Biometals 2017, 30, 285-293. [CrossRef] [PubMed]

93. Reybier, K.; Ayala, S.; Alies, B.; Rodrigues, J.V.; Bustos-Rodriguez, S.; La Penna, G.; Collin, F.; Gomes, C.M.; Hureau, C.; Faller, P. Free superoxide is an intermediate in the production of $\mathrm{H}_{2} \mathrm{O}_{2}$ by copper(I)-A $\beta$ peptide and $\mathrm{O}_{2}$. Angew. Chem. Int. Ed. Engl. 2016, 55, 1085-1089. [CrossRef] [PubMed]

94. Smith, M.A.; Harris, P.L.; Sayre, L.M.; Perry, G. Iron accumulation in Alzheimer disease is a source of redox-generated free radicals. Proc. Natl. Acad. Sci. USA 1997, 94, 9866-9868. [CrossRef] [PubMed]

95. Zawisza, I.; Rózga, M.; Bal, W. Affinity of copper and zinc ions to proteins and peptides related to neurodegenerative conditions (A $\beta$, APP, $\alpha$-synuclein, PrP). Coord. Chem. Rev. 2012, 256, 2297-2307. [CrossRef]

96. Migliorini, C.; Porciatti, E.; Luczkowski, M.; Valensin, D. Structural characterization of $\mathrm{Cu}^{2+}, \mathrm{Ni}^{2+}$ and $\mathrm{Zn}^{2+}$ binding sites of model peptides associated with neurodegenerative diseases. Coord. Chem. Rev. 2012, 256, 352-368. [CrossRef]

97. Noel, S.; Bustos Rodriguez, S.; Sayen, S.; Guillon, E.; Faller, P.; Hureau, C. Use of a new water-soluble $\mathrm{Zn}$ sensor to determine $\mathrm{Zn}$ affinity for the amyloid- $\beta$ peptide and relevant mutants. Metallomics 2014, 6 , 1220-1222. [CrossRef] [PubMed]

98. Habtemariam, S.; Varghese, G.K. A novel diterpene skeleton: Identification of a highly aromatic, cytotoxic and antioxidant 5-methyl-10-demethyl-abietane-type diterpene from Premna serratifolia. Phyther. Res. 2015, 29, 80-85. [CrossRef] [PubMed]

99. Habtemariam, S. Investigation into the antioxidant and antidiabetic potential of Moringa stenopetala: Identification of the active principles. Nat. Prod. Commun. 2015, 10, 475-478. [PubMed]

100. Habtemariam, S.; Varghese, G.K. Extractability of rutin in herbal tea preparations of Moringa stenopetala leaves. Beverages 2015, 1, 169-182. [CrossRef]

101. Habtemariam, S.; Varghese, G.K. The antidiabetic therapeutic potential of dietary polyphenols. Curr. Pharm. Biotechnol. 2014, 15, 391-400. [CrossRef] [PubMed]

102. Habtemariam, S.; Cowley, R.A. Cowley, Antioxidant and anti- $\alpha$-glucosidase ccompounds from the rhizome of Peltiphyllum peltatum (Torr.) Engl. Phytother. Res. 2012, 26, 1656-1660. [CrossRef] [PubMed]

103. Roselli, M.; Lentini, G.; Habtemariam, S. Phytochemical, antioxidant and anti- $\alpha$-glucosidase activity evaluations of Bergenia cordifolia. Phyther. Res. 2012, 26, 908-914. [CrossRef] [PubMed]

104. Habtemariam, S. Methyl-3-O-methyl gallate and gallic acid from the leaves of Peltiphyllum peltatum: Isolation and comparative antioxidant, prooxidant, and cytotoxic effects in neuronal cells. J. Med. Food 2011, 14, 1412-1418. [CrossRef] [PubMed]

105. Juan-Badaturuge, M.; Habtemariam, S.; Thomas, M.J.K. Antioxidant compounds from a South Asian beverage and medicinal plant, Cassia auriculata. Food. Chem. 2011, 125, 221-225. [CrossRef] 
106. Habtemariam, S.; Dagne, E. Comparative antioxidant, prooxidant and cytotoxic activity of sigmoidin A and eriodictyol. Planta Med. 2010, 76, 589-594. [CrossRef] [PubMed]

107. Juan-Badaturugea, M.; Habtemariam, S.; Jackson, C.; Thomas, M.J.K. Antioxidant principles of Tanacetum vulgare L. aerial part. Nat. Prod. Commun. 2009, 4, 1561-1564.

108. Habtemariam, S. Activity-guided isolation and identification of free radical-scavenging components from ethanolic extract of boneset (Leaves of Eupatorium perfoliatum). Nat. Prod. Commun. 2008, 3, 1317-1320.

109. Habtemariam, S.; Jackson, C. Antioxidant and cytoprotective activity of leaves of Peltiphyllum peltatum (Torr.) Engl. Food Chem. 2007, 105, 498-503. [CrossRef]

110. Habtemariam, S. Modulation of tumour necrosis factor- $\alpha$-induced cytotoxicity by polyphenols. Phyther. Res. 1997, 11, 277-280. [CrossRef]

111. Habtemariam, S. Flavonoids as inhibitors or enhancers of the cytotoxicity of tumor necrosis factor-alpha in L-929 tumor cells. J. Nat. Prod. 1997, 60, 775-778. [CrossRef] [PubMed]

112. Habtemariam, S. Catechols and quercetin reduce MTT through iron ions: A possible artefact in cell viability assay. Phyther. Res. 1995, 9, 603-605. [CrossRef]

113. Varghese, G.K.; Bose, L.V.; Habtemariam, S. Antidiabetic components of Cassia alata leaves: Identification through $\alpha$-glucosidase inhibition studies. Pharm. Biol. 2013, 51, 345-349. [CrossRef] [PubMed]

114. Habtemariam, S. Antihyperlipidemic components of Cassia auriculata aerial parts: Identification through in vitro studies. Phytother. Res. 2013, 27, 152-155. [CrossRef] [PubMed]

115. Habtemariam, S. $\alpha$-Glucosidase inhibitory activity of kaempferol-3-O-rutinoside. Nat. Prod. Commun. 2011, 6, 201-203. [PubMed]

116. Li, C.; Zhao, R.; Gao, K.; Wei, Z.; Yin, M.Y.; Lau, L.T.; Chui, D.; Yu, A.C. Astrocytes: Implications for neuroinflammatory pathogenesis of Alzheimer's disease. Curr. Alzheimer Res. 2011, 8, 67-80. [CrossRef] [PubMed]

117. Garwood, C.J.; Ratcliffe, L.E.; Simpson, J.E.; Heath, P.R.; Ince, P.G.; Wharton, S.B. Astrocytes in Alzheimer's disease and other age-associated dementias: A supporting player with a central role. Neuropathol. Appl. Neurobiol. 2017, 43, 281-298. [CrossRef] [PubMed]

118. McGeer, P.L.; Itagaki, S.; Tago, H.; Mcgeer, E.G. Reactive microglia in patients with senile dementia of the Alzheimer type are positive for the histocompatibility glycoprotein HLA-DR. Neurosci. Lett. 1987, 79, 195-200. [CrossRef]

119. Schwab, C.; McGeer, P.L. Inflammatory aspects of Alzheimer disease and other neurodegenerative disorders. J. Alzheimers Dis. 2008, 13, 359-369. [CrossRef] [PubMed]

120. Hoeijmakers, L.; Heinen, Y.; Van Dam, A.M.; Lucassen, P.J.; Korosi, A. Microglial priming and Alzheimer's disease: A possible role for (early) immune challenges and epigenetics? Front. Hum. Neurosci. 2016, 10, 398. [CrossRef] [PubMed]

121. Zuroff, L.; Daley, D.; Black, K.L.; Koronyo-Hamaoui, M. Clearance of cerebral A $\beta$ in Alzheimer's disease: Reassessing the role of microglia and monocytes. Cell Mol. Life Sci. 2017, 74, 2167-2201. [CrossRef] [PubMed]

122. Heppner, F.L.; Ransohoff, R.M.; Becher, B. Immune attack: The role of inflammation in Alzheimer disease. Nat. Rev. Neurosci. 2015, 16, 358-372. [CrossRef] [PubMed]

123. Shamim, D.; Laskowski, M. Inhibition of inflammation mediated through the tumor Necrosis factor- $\alpha$ biochemical pathway can lead to favorable outcomes in Alzheimer disease. J. Cent. Nerv. Syst. Dis. 2017, 9. [CrossRef] [PubMed]

124. Decourt, B.; Lahiri, D.K.; Sabbagh, M.N. Targeting tumor necrosis factor- $\alpha$ for Alzheimer's disease. Curr. Alzheimer Res. 2017, 14, 412-425. [CrossRef] [PubMed]

125. Shi, Z.M.; Han, Y.W.; Han, X.H.; Zhang, K.; Chang, Y.N.; Hu, Z.M.; Qi, H.X.; Ting, C.; Zhen, Z.; Hong, W. Upstream regulators and downstream effectors of NF-кB in Alzheimer's disease. J. Neurol. Sci. 2016, 366, 127-134. [CrossRef] [PubMed]

126. O’Malley, D.; MacDonald, N.; Mizielinska, S.; Connolly, C.N.; Irving, A.J.; Harvey, J. Leptin promotes rapid dynamic changes in hippocampal dendritic morphology. Mol. Cell Neurosci. 2007, 35, 559-572. [CrossRef] [PubMed]

127. Brennan, A.M.; Mantzoros, C.S. Drug insight: The role of leptin in human physiology and pathophysiology-emerging clinical applications. Nat. Clin. Pract. Endocrinol. Metab. 2006, 2, 318-327. [CrossRef] [PubMed] 
128. Garza, J.C.; Guo, M.; Zhang, W.; Lu, X.Y. Leptin increases adult hippocampal neurogenesis in vivo and in vitro. J. Biol. Chem. 2008, 283, 18238-18247. [CrossRef] [PubMed]

129. Bonda, D.J.; Stone, J.G.; Torres, S.L.; Siedlak, S.L.; Perry, G.; Kryscio, R.; Jicha, G.; Casadesus, G.; Smith, M.A.; $\mathrm{Zhu}, \mathrm{X}$; et al. Dysregulation of leptin signaling in Alzheimer disease: Evidence for neuronal leptin resistance. J. Neurochem. 2014, 128, 162-172. [CrossRef] [PubMed]

130. Holden, K.F.; Lindquist, K.; Tylavsky, F.A.; Rosano, C.; Harris, T.B.; Yaffe, K. Serum leptin level and cognition in the elderly: Findings from the Health ABC Study. Neurobiol. Aging 2009, 30, 1483-1489. [CrossRef] [PubMed]

131. Khemka, V.K.; Bagchi, D.; Bandyopadhyay, K.; Bir, A.; Chattopadhyay, M.; Biswas, A.; Basu, D.; Chakrabarti, S. Altered serum levels of adipokines and insulin in probable Alzheimer's disease. J. Alzheimers Dis. 2014, 41, 525-533. [CrossRef] [PubMed]

132. Lieb, W.; Beiser, A.S.; Vasan, R.S.; Tan, Z.S.; Au, R.; Harris, T.B.; Roubenoff, R.; Auerbach, S.; DeCarli, C.; Wolf, P.A.; et al. Association of plasma leptin levels with incident Alzheimer disease and MRI measures of brain aging. JAMA 2009, 302, 2565-2572. [CrossRef] [PubMed]

133. Ahima, R.S.; Bjorbaek, C.; Osei, S.; Flier, J.S. Regulation of neuronal and glial proteins by leptin: Implications for brain development. Endocrinology 1999, 140, 2755-2762. [CrossRef] [PubMed]

134. Kim, J.G.; Suyama, S.; Koch, M.; Jin, S.; Argente-Arizon, P.; Argente, J.; Liu, Z.W.; Zimmer, M.R.; Jeong, J.K.; Szigeti-Buck, K.; et al. Leptin signaling in astrocytes regulates hypothalamic neuronal circuits and feeding. Nat. Neurosci. 2014, 17, 908-910. [CrossRef] [PubMed]

135. Dicou, E.; Attoub, S.; Gressens, P. Neuroprotective effects of leptin in vivo and in vitro. Neuroreport 2001, 12, 3947-3951. [CrossRef] [PubMed]

136. Lu, J.; Park, C.S.; Lee, S.K.; Shin, D.W.; Kang, J.H. Leptin inhibits 1-methyl-4-phenylpyridinium-induced cell death in SH-SY5Y cells. Neurosci. Lett. 2006, 407, 240-243. [CrossRef] [PubMed]

137. Zhang, F.; Chen, J. Leptin protects hippocampal CA1 neurons against ischemic injury. J. Neurochem. 2008, 107, 578-587. [CrossRef] [PubMed]

138. Cook, D.G.; Leverenz, J.B.; McMillan, P.J.; Kulstad, J.J.; Ericksen, S.; Roth, R.A.; Schellenberg, G.D.; Jin, L.W.; Kovacina, K.S.; Craft, S. Reduced hippocampal insulin-degrading enzyme in late-onset Alzheimer's disease is associated with the apolipoprotein E-epsilon4 allele. Am. J. Pathol. 2003, 162, 313-319. [CrossRef]

139. Iwata, N.; Tsubuki, S.; Takaki, Y.; Shirotani, K.; Lu, B.; Gerard, N.P.; Gerard, C.; Hama, E.; Lee, H.J.; Saido, T.C. Metabolic regulation of brain A $\beta$ by neprilysin. Science 2001, 292, 1550-1552. [CrossRef] [PubMed]

140. Leal, M.C.; Dorfman, V.B.; Gamba, A.F.; Frangione, B.; Wisniewski, T.; Castaño, E.M.; Sigurdsson, E.M.; Morelli, L. Plaque-associated overexpression of insulin-degrading enzyme in the cerebral cortex of aged transgenic tg2576 mice with Alzheimer pathology. J. Neuropathol. Exp. Neurol. 2006, 65, 976-987. [CrossRef] [PubMed]

141. Vekrellis, K.; Ye, Z.; Qiu, W.Q.; Walsh, D.; Hartley, D.; Chesneau, V.; Rosner, M.R.; Selkoe, D.J. Neurons regulate extracellular levels of amyloid beta-protein via proteolysis by insulin-degrading enzyme. J. Neurosci. 2000, 20, 1657-1665. [PubMed]

142. Qiu, W.Q.; Walsh, D.M.; Ye, Z.; Vekrellis, K.; Zhang, J.; Podlisny, M.B.; Rosner, M.R.; Safavi, A.; Hersh, L.B.; Selkoe, D.J. Insulin-degrading enzyme regulates extracellular levels of amyloid beta-protein by degradation. J. Biol. Chem. 1998, 273, 32730-32738. [CrossRef] [PubMed]

143. Son, S.M.; Cha, M.Y.; Choi, H.; Kang, S.; Choi, H.; Lee, M.S.; Park, S.A.; Mook-Jung, I. Insulin-degrading enzyme secretion from astrocytes is mediated by an autophagy-based unconventional secretory pathway in Alzheimer disease. Autophagy 2016, 12, 784-800. [CrossRef] [PubMed]

144. Caccamo, A.; Oddo, S.; Sugarman, M.C.; Akbari, Y.; LaFerla, F.M. Age- and region-dependent alterations in A $\beta$-degrading enzymes: Implications for A $\beta$-induced disorders. Neurobiol. Aging. 2005, 26, 645-654. [CrossRef] [PubMed]

145. El-Amouri, S.S.; Zhu, H.; Yu, J.; Marr, R.; Verma, I.M.; Kindy, M.S. Neprilysin: An enzyme candidate to slow the progression of Alzheimer's disease. Am. J. Pathol. 2008, 172, 1342-1354. [CrossRef] [PubMed]

146. Nalivaeva, N.N.; Beckett, C.; Belyaev, N.D.; Turner, A.J. Are amyloid-degrading enzymes viable therapeutic targets in Alzheimer's disease? J. Neurochem. 2012, 120, 167-185. [CrossRef] [PubMed]

147. Turner, A.J.; Nalivaeva, N.N. New insights into the roles of metalloproteinases in neurodegeneration and neuroprotection. Int. Rev. Neurobiol. 2007, 82, 113-135. [CrossRef] [PubMed] 
148. Ries, M.; Sastre, M. Mechanisms of A $\beta$ clearance and degradation by glial cells. Front. Aging Neurosci. 2016, 8, 160. [CrossRef] [PubMed]

149. Guzmán-Martinez, L.; Farías, G.A.; Maccioni, R.B. Tau oligomers as potential targets for Alzheimer's diagnosis and novel drugs. Front. Neurol. 2013, 4, 167. [CrossRef] [PubMed]

150. Mi, K.; Johnson, G.V. The role of tau phosphorylation in the pathogenesis of Alzheimer's disease. Curr. Alzheimer Res. 2006, 3, 449-463. [CrossRef] [PubMed]

151. Alonso, A.C.; Zaidi, T.; Grundke-Iqbal, I.; Iqbal, K. Role of abnormally phosphorylated tau in the breakdown of microtubules in Alzheimer disease. Proc. Natl. Acad. Sci. USA 1994, 91, 5562-5566. [CrossRef] [PubMed]

152. Cho, J.H.; Johnson, G.V. Primed phosphorylation of tau at Thr231 by glycogen synthase kinase 3 beta (GSK3beta) plays a critical role in regulating tau's ability to bind and stabilize microtubules. J. Neurochem. 2004, 88, 349-358. [CrossRef] [PubMed]

153. Wagner, U.; Utton, M.; Gallo, J.M.; Miller, C.C. Cellular phosphorylation of tau by GSK-3 $\beta$ influences tau binding to microtubules and microtubule organization. J. Cell Sci. 1996, 109, 1537-1543. [PubMed]

154. Rojo, A.I.; Sagarra, M.R.; Cuadrado, A. GSK-3 $\beta$ down-regulates the transcription factor Nrf2 after oxidant damage: Relevance to exposure of neuronal cells to oxidative stress. J. Neurochem. 2008, 105, 192-202. [CrossRef] [PubMed]

155. Munoz, L.; Ammit, A.J. Targeting p38 MAPK pathway for the treatment of Alzheimer's disease. Neuropharmacology 2010, 58, 561-568. [CrossRef] [PubMed]

156. Kim, E.K.; Choi, E.J. Compromised MAPK signaling in human diseases: An update. Arch. Toxicol. 2015, 89, 867-882. [CrossRef] [PubMed]

157. Cuenda, A.; Rousseau, S. p38 MAP-kinases pathway regulation, function and role in human diseases. Biochim. Biophys. Acta 2007, 1773, 1358-1375. [CrossRef] [PubMed]

158. Medina, M.; Garrido, J.J.; Wandosell, F.G. Modulation of GSK-3 as a therapeutic strategy on tau pathologies. Front. Mol. Neurosci. 2011, 4, 24. [CrossRef] [PubMed]

159. Jhang, K.A.; Park, J.S.; Kim, H.S.; Chong, Y.H. Resveratrol Ameliorates Tau Hyperphosphorylation at Ser396 Site and Oxidative Damage in Rat Hippocampal Slices Exposed to Vanadate: Implication of ERK1/2 and GSK-3 $\beta$ Signaling Cascades. J. Agric. Food. Chem. 2017, 65, 9626-9634. [CrossRef] [PubMed]

160. Sun, J.; Zhang, X.; Wang, C.; Teng, Z.; Li, Y. Curcumin decreases hyperphosphorylation of tau by down-regulating caveolin-1/GSK-3 $\beta$ in N2a/APP695swe cells and APP/PS1 double transgenic Alzheimer's disease mice. Am. J. Chin. Med. 2017, 45, 1667-1682. [CrossRef] [PubMed]

161. Huang, W.; Cheng, P.; Yu, K.; Han, Y.; Song, M.; Li, Y. Hyperforin attenuates aluminum-induced $\mathrm{A} \beta$ production and tau phosphorylation via regulating Akt/GSK-3 $\beta$ signaling pathway in PC12 cells. Biomed. Pharmacother. 2017, 96, 1-6. [CrossRef] [PubMed]

162. Xu, W.; Liu, J.; Ma, D.; Yuan, G.; Lu, Y.; Yang, Y. Capsaicin reduces Alzheimer-associated tau changes in the hippocampus of type 2 diabetes rats. PLoS ONE 2017, 12, e0172477. [CrossRef] [PubMed]

163. Tian, S.; Wang, J.; Li, Y.; Li, D.; Xu, L.; Hou, T. The application of in silico drug-likeness predictions in pharmaceutical research. Adv. Drug Deliv. Rev. 2015, 86, 2-10. [CrossRef] [PubMed]

164. Liu, Z.Q.; Jiang, Z.H.; Liu, L.; Hu, M. Mechanisms responsible for poor oral bioavailability of paeoniflorin: Role of intestinal disposition and interactions with sinomenine. Pharm. Res. 2006, 23, 2768-2780. [CrossRef] [PubMed]

165. Cheng, C.; Lin, J.-Z.; Li, L.; Yang, J.-L.; Jia, W.-W.; Huang, W.-H.; Du, F.-F.; Wang, F.-Q.; Li, M.-J.; Li, Y.-F.; et al. Pharmacokinetics and disposition of monoterpene glycosides derived from Paeonia lactiflora roots (Chishao) after intravenous dosing of antiseptic XueBijing injection in human subjects and rats. Acta Pharmacol. Sin. 2016, 37, 530-544. [CrossRef] [PubMed]

166. Martey, O.N.K.; Shi, X.; He, X. Advance in pre-clinical pharmacokinetics of paeoniflorin, a major monoterpene glucoside from the root of Paeonia lactiflora. Pharmacol. Pharm. 2013, 4, 4-14. [CrossRef]

167. Austgulen, L.T.; Solheim, E.; Scheline, R.R. Metabolism in rats of $p$-cymene derivatives: Carvacrol and thymol. Pharmacol. Toxicol. 1987, 61, 98-102. [CrossRef] [PubMed]

168. Dong, R.H.; Fang, Z.Z.; Zhu, L.L.; Liang, S.C.; Ge, G.B.; Liu, Z.Y. Investigation of UDP-glucuronosyltransferases (UGTs) inhibitory properties of carvacrol. Phytother. Res. 2012, 26, 86-90. [CrossRef] [PubMed] 
169. Kohlert, C.; Schindler, G.; März, R.W.; Abel, G.; Brinkhaus, B.; Derendorf, H.; Gräfe, E.U.; Veit, M. Systemic availability and pharmacokinetics of thymol in humans. J. Clin. Pharmacol. 2002, 42, 731-737. [CrossRef] [PubMed]

170. Miller, J.A.; Lang, J.E.; Ley, M.; Nagle, R.; Hsu, C.H.; Thompson, P.A.; Cordova, C.; Waer, A.; Chow, H.H. Human breast tissue disposition and bioactivity of limonene in women with early stage breast cancer. Cancer Prev. Res. 2013, 6, 577-584. [CrossRef] [PubMed]

171. Miller, J.A.; Hakim, I.A.; Chew, W.; Thompson, P.; Thomson, C.A.; Chow, H.H. Adipose tissue accumulation of D-limonene with the consumption of a lemonade preparation rich in D-limonene content. Nutr. Cancer 2010, 62, 783-788. [CrossRef] [PubMed]

172. Li, H.L.; He, J.C.; Bai, M.; Song, Q.Y.; Feng, E.F.; Rao, G.X.; Xu, G.L. Determination of the plasma pharmacokinetic and tissue distributions of swertiamarin in rats by liquid chromatography with tandem mass spectrometry. Arzneimittelforschung 2012, 62, 138-144. [CrossRef] [PubMed]

173. Cheng, S.; Lin, L.C.; Lin, C.H.; Tsai, T.H. Comparative oral bioavailability of geniposide following oral administration of geniposide, Gardenia jasminoides Ellis fruits extracts and Gardenia herbal formulation in rats. J. Pharm. Pharmacol. 2014, 66, 705-712. [CrossRef] [PubMed]

174. Akao, T.; Kobashi, K.; Aburasa, M. Enzymic studies on the animal and intestinal bacterial metabolism of geniposide. Biol. Pharm. Bull. 1994, 17, 1573-1576. [CrossRef] [PubMed]

175. Chen, C.; Han, F.; Zhang, Y.; Lu, J.; Shi, Y. Simultaneous determination of geniposide and its metabolites genipin and genipinine in culture of Aspergillus niger by HPLC. Biomed. Chromatogr. 2008, 22, 753-757. [CrossRef] [PubMed]

176. Han, H.; Yang, L.; Xu, Y.; Ding, Y.; Annie Bligh, S.W.; Zhang, T.; Wang, Z.T. Identification of metabolites of geniposide in rat urine using ultra-performance liquid chromatography combined with electrospray ionization quadrupole time-of-flight tandem mass spectrometry. Rapid Commun. Mass Spectrom. 2011, 25, 3339-3350. [CrossRef] [PubMed]

177. Habtemariam, S.; Belai, A. Natural therapies of the inflammatory bowel disease: The case of rutin and its aglycone, quercetin. Mini Rev. Med. Chem. 2017, 17. in press. [CrossRef]

178. Yu, B.; Ruan, M.; Cui, X.B.; Guo, J.M.; Xu, L.; Dong, X.P. Effect of borneol on the pharmacokinetics of geniposide in cortex, hippocampus, hypothalamus and striatum of conscious rat by simultaneous microdialysis coupled with UPLC-MS. J. Pharm. Biomed. Anal. 2013, 77, 128-132. [CrossRef] [PubMed]

179. Maggio, A.; Rosselli, S.; Bruno, M. Essential oils and pure volatile compounds as potential drugs in Alzheimer's disease therapy: An updated review of the literature. Curr. Pharm. Des. 2016, 22, 4011-4027. [CrossRef] [PubMed]

(C) 2018 by the author. Licensee MDPI, Basel, Switzerland. This article is an open access article distributed under the terms and conditions of the Creative Commons Attribution (CC BY) license (http://creativecommons.org/licenses/by/4.0/). 